\title{
Hepatitis B virus and its sexually transmitted infection - an update
}

\author{
Takako Inoue ${ }^{1}$ and Yasuhito Tanaka ${ }^{1,2, *}$ \\ ${ }^{1}$ Clinical Laboratory, Nagoya City University Hospital, Nagoya, Japan. \\ ${ }^{2}$ Department of Virology \& Liver unit, Nagoya City University Graduate School of Medical Sciences, Nagoya, Japan. \\ * Corresponding Author: \\ Yasuhito Tanaka, M.D., Ph.D., Department of Virology \& Liver unit, Nagoya City University Graduate School of Medical Sciences, \\ Kawasumi, Mizuho; Nagoya 467-8601, Japan; Tel: +81-52-853-8191; Fax: +81-52-842-0021; E-mail: ytanaka@med.nagoya-cu.ac.jp
}

ABSTRACT Epidemiology: incidence and prevalence: About $5 \%$ of the world's population has chronic hepatitis B virus (HBV) infection, and nearly $25 \%$ of carriers develop chronic hepatitis, cirrhosis, and hepatocellular carcinoma (HCC). The prevalence of chronic HBV infection in human immunodeficiency virus (HIV)-infected individuals is $5 \%-15 \%$; HIV/HBV coinfected individuals have a higher level of $\mathrm{HBV}$ replication, with higher rates of chronicity, reactivation, occult infection, and HCC than individuals with HBV only. The prevalence of $\mathrm{HBV}$ genotype $A$ is significantly higher among men who have sex with men (MSM), compared with the rest of the population. Molecular mechanisms of infection, pathology, and symptomatology: HBV replication begins with entry into the hepatocyte. Sodium taurocholate cotransporting polypeptide was identified in 2012 as the entry receptor of HBV. Although chronic hepatitis B develops slowly, HIV/HBV coinfected individuals show more rapid progression to cirrhosis and HCC. Transmission and protection: The most common sources of HBV infection are body fluids. Hepatitis B (HB) vaccination is recommended for all children and adolescents, and all unvaccinated adults at risk for HBV infection (sexually active individuals such as MSM, individuals with occupational risk, and immunosuppressed individuals). Although HB vaccination can prevent clinical infections (hepatitis), it cannot prevent $100 \%$ of subclinical infections. Treatment and curability: The goal of treatment is reducing the risk of complications (cirrhosis and HCC). Pegylated interferon alfa and nucleos(t)ide analogues (NAs) are the current treatments for chronic HBV infection. NAs have improved the outcomes of patients with cirrhosis and HCC, and decreased the incidence of acute liver failure. doi: 10.15698/mic2016.09.527

Received originally: 04.12.2015;

in revised form: 29.04.2016,

Accepted 17.05.2016,

Published 05.09.2016.

Keywords: Hepatitis B virus, Sexually transmitted infection, HIV/HBV coinfection,

Genotype A,

Hepatitis $B$ vaccine.

\section{Abbreviations:}

ALT - alanine aminotransferase, DNA Pol - DNA polymerase,

$H B$ - Hepatitis $B$,

$H B C A g$ - hepatitis $B$ core antigen,

$H B s A g$ - hepatitis B surface antigen,

$H B V$ - hepatitis $B$ virus,

HCC - hepatocellular carcinoma,

HIV - human immunodeficiency virus,

MSM - men who have sex with men,

$N A s$ - nucleos(t)ide analogues,

$R T$ - reverse transcriptase,

STD - sexually transmitted disease,

$S T I$ - sexually transmitted infection,

SVR - sustained virological response.

\section{INTRODUCTION}

A sexually transmitted infection (STI) is defined as an infection that results from transmission of a pathogenic organism by sexual contact (i.e., any genital or anal contact with another person's genitals, anus, or mouth) and that accounts for a noticeable amount of illness in the general population or in a defined subpopulation [1, 2]. Although there is no consensus on when the terms STI and sexually transmitted disease (STD) should be used, the American Sexual Health Association (ASHA) makes a distinction between the two terms [3]. The concept of "a disease," as in
STD, suggests a clear medical problem, usually some obvious signs or symptoms. However, most people infected with one or the other of several of the most common STIs do not manifest signs or symptoms, or have mild signs and symptoms that can be easily overlooked. A sexually transmitted virus or bacterium can infect its host, which may or may not result in "a disease." In this article, we use the term STI.

Organisms such as hepatitis B virus (HBV) that cause infections via sexual transmission can also cause infections via other routes, such as percutaneous transmission by 
contaminated needles and vertical transmission in utero or during delivery. As a typical STI, HBV infection is present in all types of populations. Sexual contact and vertical transmission from mother to infant are responsible for the large majority of HBV infections worldwide [4].

HBV infection as an STI is well documented. It is mainly common among men who have sex with men (MSM), because multiple partners are common in this population; and anal sex is usually more traumatic than vaginal intercourse, resulting in increased risk of exposure to blood [4, 5]. HBV infection is also extremely common among heterosexual individuals who have multiple sex partners or contact with sex workers [6].

Routine immunization with hepatitis $B(H B)$ vaccine is strongly recommended for the prevention of HBV infection in MSM and other individuals at risk for STIs. HB vaccination of adults has been found to be effective at conferring immunity to individuals who are exposed to HBV via sexual transmission. However, the first priority is directly preventing the spread of HBV by the most reliable and appropriate method, which is use of a condom for safe sexual contact.

Chronic HBV infection is the cause of chronic hepatitis, cirrhosis, and hepatocellular carcinoma (HCC) [7]. The goals of antiviral therapy for patients with chronic HBV are to slow the progression of chronic liver disease and decrease the development of complications, including cirrhosis and HCC. At present, pegylated interferon alfa (PEG-IFN- $\alpha$ ), entecavir, and tenofovir disoproxil fumarate (tenofovir) are available for the treatment of HBV infection [8]. Sodium taurocholate cotransporting polypeptide (NTCP) was recently identified as the receptor for HBV entry into hepatocytes [9]. Because NTCP is essential for HBV infection, it may have potential as a new therapeutic target.

The purpose of this article is to provide up-to-date information on HBV and HBV infection as a major STI.

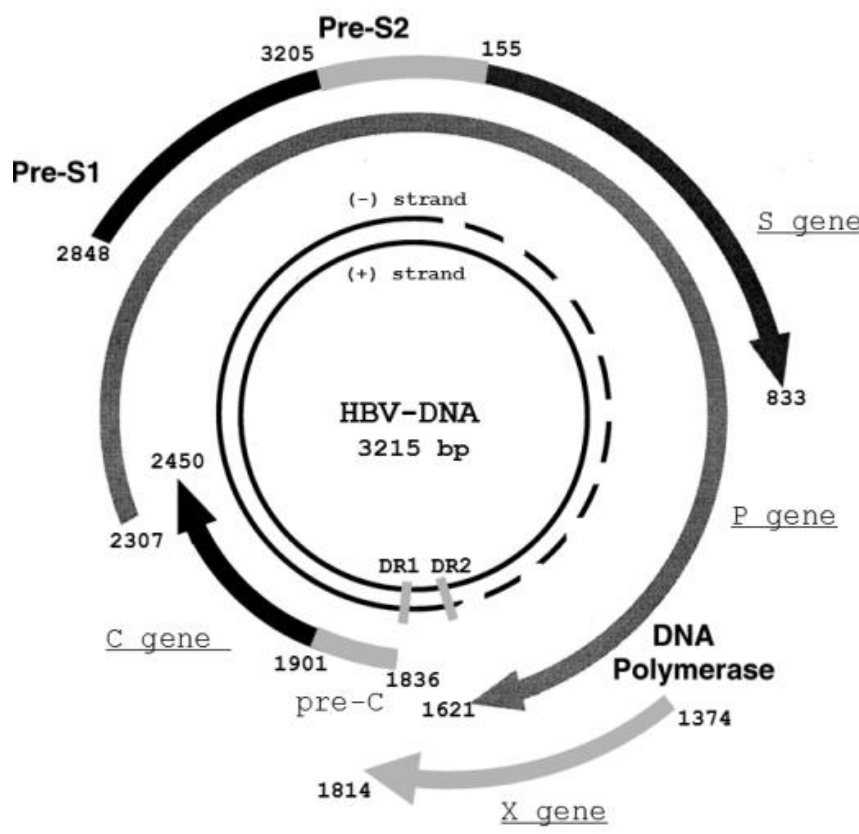

\section{ETIOLOGY AND MECHANISMS OF HBV INFECTION Etiology \\ Hepatitis B virus (HBV)}

$\mathrm{HBV}$ is classified in the family Hepadnaviridae. It is a very small, partially double-stranded DNA virus. Humans are known to be the only natural host. HBV reaches the liver through the systemic circulation and can only replicate in hepatocytes [10]. Since HBV is a hepatotropic virus, injury to the liver results from the immune-mediated destruction of infected hepatocytes [6].

The infectious $\mathrm{HB}$ virion has a diameter of $42-47 \mathrm{~nm}$ and is a double-shelled particle in serum. Its concentration can be as high as 108 virions per $\mathrm{mL}[6,10]$. The infectious $\mathrm{HB}$ virion consists of an outer lipoprotein coat (also called envelope) containing hepatitis $B$ surface antigen ( $\mathrm{HBsAg}$ ). HBsAg surrounds an inner nucleocapsid composed of hepatitis $B$ core antigen ( $\mathrm{HBcAg}$ ) that encapsidates the HBV genome and DNA polymerase $[11,12]$.

\section{Genome structure and proteins}

The HBV genome consists of a partially double-stranded, circular DNA molecule. Its total genome is $1700-2800 \mathrm{nu}$ cleotides long or 3020-3320 nucleotides long (for the short and full-length strand, respectively). Every nucleotide in the genome is active in 4 highly overlapping coding regions, or open reading frames (ORFs), as shown in Fig. 1 $[13,14,15,16]$. The polymerase gene (P gene) encodes the key enzyme for replication of the genome [13]. The enzyme has DNA polymerase (DNA Pol), reverse transcriptase (RT) and RNase $\mathrm{H}$ activities, and also acts as the terminal protein (TP) $[13,17]$. The core gene (C gene) has at least two in-frame start codons, and encodes $\mathrm{HBCAg}$ and $\mathrm{HBeAg}$ [13]. HBcAg is the protein that encapsidates the viral DNA. It can also be expressed on the surface of hepatocytes, and evokes the cellular immune response [18]. HBeAg is a marker of active viral replication [13]. Secreted HBeAg is

FIGURE 1: Structure and organization of the HBV genome [16]. The four protein-coding regions are shown by semicircular arrows. They include the precore (pre- $C$ ) and core gene ( $C$ gene); the polymerase gene ( $P$ gene); the $X$ gene; and the envelope genes pre-S1, pre-S2, and $S$ ( $S$ gene). The positions of the direct repeats (DR1 and DR2) are indicated. Genome positions may change, depending on the HBV genotype [16]. Abbreviations: $\mathrm{HBV}$, hepatitis B virus; $\mathrm{P}$ gene, the polymerase gene; $\mathrm{C}$ gene, the core gene; $S$ gene, the surface gene. 
significantly more efficient than intracellular $\mathrm{HBcAg}$ at producing T-cell tolerance [19]. The surface gene (S gene) encodes three different envelope glycoproteins, known as the pre-S1, pre-S2, and S proteins. The pre-S1 protein (large HBsAg) is the largest of the HBV surface proteins, and is produced starting at the first initiation codon of the ORF. The pre-S2 protein (middle HBsAg) is produced starting at the second initiation codon. The $S$ protein (small $\mathrm{HBsAg}$ ), which is commonly referred to as $\mathrm{HBsAg}$ or the Australia antigen, is produced starting at the third initiation codon. The $X$ gene encodes the multifunctional $X$ protein [13]. It controls the level of HBV replication and acts as a cofactor in the development of HCC [20].

\section{Natural history of HBV infection}

HBV infection can cause acute hepatitis, acute liver failure, or chronic hepatitis, or can cause an asymptomatic infection. Chronic HBV infection can result in cirrhosis or HCC.
The probability that a person with HBV infection will progress to chronic infection is strongly dependent on the person's age at the time of HBV infection [21]. More than $90 \%$ of HBV-infected infants and $25 \%-50 \%$ of children infected between the ages of 1 and 5 years will develop chronic hepatitis. More than $25 \%$ of HBV-infected infants and children older than 6 years will develop HBV-related cirrhosis and HCC [10]. The rate of progression to cirrhosis and $\mathrm{HCC}$ is less than $1 \%$ per year for patients in the inactive chronic hepatitis stage, while the rate of progression to cirrhosis may be $2 \%-10 \%$ per year for patients in the immune active stage. By contrast, less than $10 \%$ of older children and adults with acute hepatitis progress to chronic infection. The progression from cirrhosis to HCC may occur in $2 \%-4 \%$ of adult patients per year [22].

In addition to age when first infected, the rates of progression of HBV infection are generally affected by gender, the level of HBV replication, HBV genotypes and variants,

Table 1. Stages of chronic HBV infection [6].

\begin{tabular}{|c|c|c|c|}
\hline Stage & $\begin{array}{c}\text { HBeAg serological } \\
\text { status }\end{array}$ & Pattern & $\begin{array}{l}\text { Indications for } \\
\text { treatment }\end{array}$ \\
\hline $\begin{array}{l}\text { 1. "Immune } \\
\text { tolerant" }\end{array}$ & HBeAg positive & $\begin{array}{l}\text { - } \\
\text { adults, particularly among those infected at birth } \\
\text { - } \quad \text { High levels of HBV replication (HBV DNA levels > } 200 \\
000 \mathrm{IU} / \mathrm{mL} \text { ) } \\
\text { - } \quad \text { Persistently normal ALT } \\
\text { - } \quad \text { Minimal histological disease }\end{array}$ & $\begin{array}{l}\text { Treatment not } \\
\text { generally } \\
\text { indicated, but } \\
\text { monitoring } \\
\text { required }\end{array}$ \\
\hline $\begin{array}{l}\text { 2. "Immune } \\
\text { active" } \\
\text { (HBeAg-positive } \\
\text { chronic hepatitis) }\end{array}$ & $\begin{array}{l}\text { HBeAg positive; } \\
\text { may develop anti- } \\
\text { HBe }\end{array}$ & $\begin{array}{l}\text { - } \\
\text { - } \\
\text { levels }>2000 \text { IU } / \mathrm{mL} \text { ) } \\
\text { - } \quad \text { Histological necroinflammatory activity present } \\
\text { - } \\
\text { HBeAg to anti-HBe seroconversion possible, with } \\
\text { normalization of ALT leading to "immune-control" stage }\end{array}$ & $\begin{array}{l}\text { Treatment may } \\
\text { be indicated }\end{array}$ \\
\hline $\begin{array}{l}\text { 3. Inactive chronic } \\
\text { hepatitis } \\
\text { "Immune control" } \\
\text { (previously called } \\
\text { inactive carrier) }\end{array}$ & $\begin{array}{l}\text { HBeAg negative, } \\
\text { anti-HBe positive }\end{array}$ & $\begin{array}{ll}- & \text { Persistently normal ALT } \\
\text { - } & \text { Low or undetectable HBV DNA (HBV DNA levels }<2000 \\
\text { IU/mL) } & \\
\text { - } & \text { Reduced risk of cirrhosis and HCC } \\
\text { - } & \text { May develop HBeAg-negative disease }\end{array}$ & $\begin{array}{l}\text { Treatment not } \\
\text { generally } \\
\text { indicated, but } \\
\text { monitoring } \\
\text { required for } \\
\text { reactivation and } \\
\text { HCC }\end{array}$ \\
\hline $\begin{array}{l}\text { 4. "Immune } \\
\text { escape" (HBeAg- } \\
\text { negative chronic } \\
\text { hepatitis) }\end{array}$ & $\begin{array}{l}\text { HBeAg negative, } \\
\text { with or without } \\
\text { anti-HBe positive }\end{array}$ & $\begin{array}{l}\text { - HBeAg negative and anti-HBe positive } \\
\text { - } \quad \text { Abnormal ALT (persistent or intermittently abnormal) } \\
\text { Moderate-to-high levels of HBV replication (HBV DNA } \\
\text { levels >20 } 000 \mathrm{lU} / \mathrm{mL} \text { ) } \\
\text { - } \quad \text { Older persons especially at risk for progressive disease } \\
\text { (fibrosis/cirrhosis) }\end{array}$ & $\begin{array}{l}\text { Treatment may } \\
\text { be indicated }\end{array}$ \\
\hline $\begin{array}{l}\text { 5. "Reactivation" } \\
\text { or "acute-on- } \\
\text { chronic hepatitis" }\end{array}$ & $\begin{array}{l}\text { HBeAg positive or } \\
\text { negative }\end{array}$ & $\begin{array}{l}\text { Can occur spontaneously or be precipitated by } \\
\text { immunosuppression from chemo- or immunosuppressive } \\
\text { therapy, HIV infection, or transplantation; development of } \\
\text { antiviral resistance; or withdrawal of antiviral therapy } \\
\text { - } \quad \text { Abnormal ALT } \\
\text { - } \quad \text { Moderate to high levels of HBV replication } \\
\text { - } \quad \text { Seroreversion to HBeAg positivity can occur if HBeAg } \\
\text { negative } \\
\text { - } \quad \text { High risk of decompensation in presence of cirrhosis }\end{array}$ & $\begin{array}{l}\text { Treatment } \\
\text { indicated }\end{array}$ \\
\hline
\end{tabular}

Abbreviations: HBV, hepatitis B virus; HBeAg, hepatitis B e antigen; ALT, alanine aminotransferase; anti-HBe, antibody to hepatitis B e antigen; HCC, hepatocellular carcinoma; HIV, human immunodeficiency virus. 
coinfecting viruses (hepatitis C virus [HCV], hepatitis delta virus [HDV], human immunodeficiency virus [HIV]), host lifestyle (drinking, smoking), exposure to carcinogenic substances, host genetic factors, and probably comorbidities (metabolic syndrome, diabetes and obesity) [22].

The natural history of chronic HBV infection can be separated into five stages, which are not necessarily sequential [23]. These stages are summarized in Table 1 [6].

Stage 1: "Immune tolerant"

The initial stage represents the incubation period. When HBV is actively replicating, HBV DNA, HBeAg, and $\mathrm{HBsAg}$ are detected in the serum [24]. The serum alanine aminotransferase (ALT) is only slightly or not elevated, and the infected person is not symptomatic. The immune response is limited to production of antibody to hepatitis B core antigen (anti-HBc) (immunoglobulin $\mathrm{M}$ [IgM] followed by immunoglobulin $\mathrm{G}$ [IgG]); however, these antibodies do not neutralize the infection [25]. This first stage occurs more frequently and has a longer duration in babies infected during delivery or during the first years of life [23]. There are only few or no findings of fibrosis. In this stage, though treatment is not generally indicated, monitoring is required. atitis

Stage 2: "Immune active" (HBeAg-positive chronic hep-

$\mathrm{HBeAg}$ can be detected in the serum. A somewhat lower level of HBV DNA is seen in some patients, who are clearing HBV, than in stage 1 [24]. Compared with the previous stage, the serum ALT level is higher, and there is moderate or severe liver necroinflammation and more rapid progression of fibrosis [23, 26, 27, 28]. For patients with chronic HBV infection, 10 years or more may pass before cirrhosis develops, immune clearance takes place, or HCC develops. The immune response reduces the level of $\mathrm{HBV}$ replication, and begins to clear $\mathrm{HBeAg}$ and $\mathrm{HBsAg}$. The rate of development of antibody to hepatitis $B$ e antigen (anti-HBe) and $\mathrm{HBeAg}$ clearance ( $\mathrm{HBeAg}$ seroconversion) is $10 \%-20 \%$ per year. Chronic infection will develop in $80 \%-90 \%$ of infected infants [29], whereas less than $5 \%$ of infected adults will fail to resolve acute hepatitis [30]. This stage ends with $\mathrm{HBeAg}$ seroconversion [23]. In this stage, treatment may be indicated.

Stage 3: Inactive chronic hepatitis "immune control" (previously called inactive carrier)

The stage of inactive chronic hepatitis may follow the seroconversion to anti-HBe and clearance of $\mathrm{HBeAg}$. The stage is characterized by very low or undetectable HBV DNA in the serum and serum aminotransferase levels in the reference range [23]. Through immunological control of HBV infection, the majority of patients will have a favorable outcome with very low risk of cirrhosis or HCC [31, 32]. HBsAg is still present in the serum, but HBsAg clearance and development of antibody to hepatitis $B$ surface antigen (anti-HBs) may occur spontaneously in $1 \%-3 \%$ of cases per year [33]. In this stage, although treatment is not generally indicated, monitoring for reactivation and HCC is required.
Stage 4: "Immune escape" (HBeAg-negative chronic hepatitis)

The HBeAg-negative chronic hepatitis stage may follow clearance of $\mathrm{HBeAg}$ and development of anti-HBe during the inactive chronic infection stage (stage 3 ) or directly from the immune active/clearance stage (stage 2). It is important to distinguish inactive HBV carriers from individuals negative for $\mathrm{HBeAg}$ who have chronic hepatitis. The former patients will have a good outcome with a very low risk of complications, while the latter have a high risk of progressive liver disease, including decompensated cirrhosis and HCC [23]. In this stage, treatment may be indicated.

Stage 5: "Reactivation" or "acute-on-chronic hepatitis"

In the final stage, HBV reactivation may occur spontaneously or may be triggered by cancer chemotherapy or other immunosuppressive therapies, and may result in serious acute-on-chronic hepatitis. Occult HBV infection is defined as persistence of HBV DNA in the liver of individuals in whom HBsAg is undetectable in the blood. Individuals who have cleared $\mathrm{HBsAg}$ and are negative for serum HBV DNA but anti-HBc positive may develop reactivation if they are being treated with potent immunosuppressive medications [6].

HBsAg loss before the onset of cirrhosis is associated with improved outcome, with a reduced risk of cirrhosis, decompensation, and HCC [23]. If cirrhosis develops before natural or treatment-induced clearance of $\mathrm{HBsAg}$, patients remain at risk of $\mathrm{HCC}$ [34]. In this stage, treatment is indicated.

\section{HBV life cycle}

NTCP was recently identified as a receptor for HBV entry, which enabled the establishment of a susceptible cell line that can efficiently support HBV infection. This discovery should lead to a deeper understanding of the requirements for effective HBV infection and clarification of the molecular mechanism of HBV entry.

The replication cycle of HBV begins with entry of the virus into hepatocytes, which is mediated by the binding of the pre-S1 region on the virion envelope to the hepatocellular NTCP [13]. The virion is then uncoated and transported into the nucleus. The viral relaxed circular DNA (rcDNA) or linear DNA genome, with a protein attached to the $5^{\prime}$ end of the minus strand and a short RNA attached to the 5' end of the plus strand [35], is converted into covalently closed circular DNA (cccDNA) through covalent ligation [14].

This cccDNA is responsible for viral persistence and is highly resistant to antiviral therapy. It serves as the template for the transcription of viral mRNAs. The pregenome mRNA serves for the synthesis of core protein (nucleocapsid subunit) and viral reverse transcriptase. The viral genome is replicated by reverse transcription of pregenomic RNA. During this process, both the protein and the RNA are removed [35]. The reverse transcriptase binds to the 5' end of its own mRNA template, and the complex is then packaged into nucleocapsids, where viral DNA synthesis occurs. These nucleocapsids can also move into the nucleus to 
increase the copy numbers of cccDNA. Since cccDNA does not undergo semiconservative replication, all cccDNA copies result from viral DNA made in the cytoplasm via the reverse transcription pathway [36].

An increase in the level of viral envelope proteins inhib- its synthesis of high levels of cccDNA, which can be toxic to hepatocytes. Once partially double-stranded DNA has been produced, nucleocapsids can undergo a maturation event that enables them to obtain an outer envelope via budding into the ER. The mature nucleocapsids may be recycled

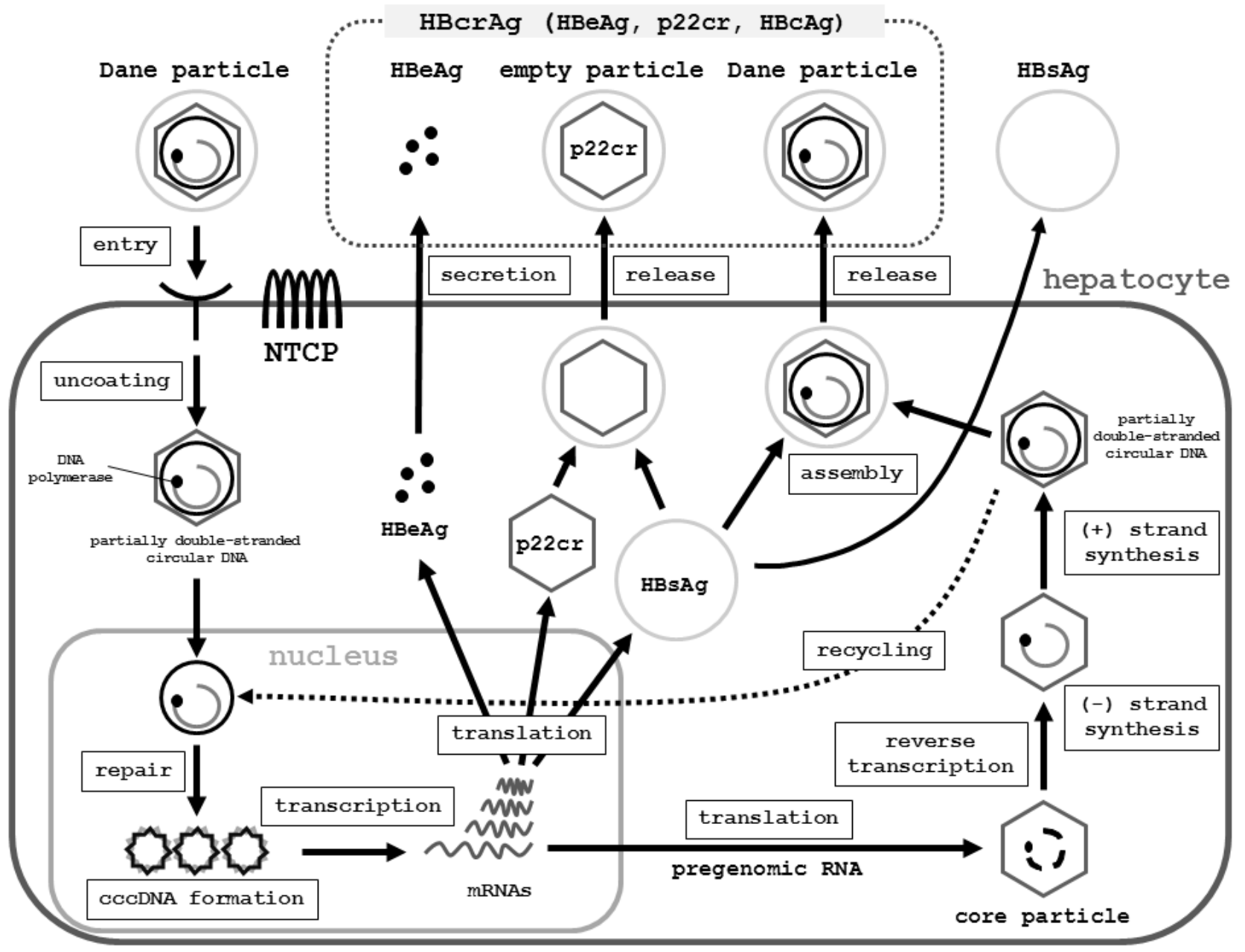

FIGURE 2: Schematic representation of the HBV lifecycle, from entry into hepatocytes to release from hepatocytes. Entry: HBV (Dane particle) obtains entry into hepatocytes by binding to the receptor NTCP [37, 38, 39] and possible additional hepatocyte-specific factors on the cell surface. The HBV membrane fuses with the membrane of the host hepatocyte, and the virion is endocytosed. Uncoating: The HBV membrane releases the viral DNA (partially double-stranded circular DNA) with the core particle into the cytoplasm [39]. The viral membrane is lost (uncoating). The viral nucleocapsid containing the viral genomic DNA is transported into the nucleus in the relaxed circular form. Repair and cccDNA formation: In the nucleus, the viral DNA polymerase synthesizes fully double-stranded DNA, and fully doublestranded DNA is converted to a cccDNA by the viral DNA polymerase [38, 39]. The formation of cccDNA remains poorly understood. It is most likely formed via the DNA repair mechanism [38]. Transcription: cccDNA is transcribed into the pregenomic and subgenomic mRNAs by host RNA polymerase [38, 39]. Translation and reverse transcription: Pregenomic RNA is the template for the translation of both DNA polymerase and the core proteins, and for reverse transcription. The DNA polymerase binds to the packaging signal of the pregenomic RNA, and both are then combined into the viral capsid, which is the core particle [38, 39]. The HBV genome matures in the core particle via reverse transcription of pregenomic mRNA to DNA [39]. DNA synthesis: After synthesis of the (-) strand DNA and (+) strand DNA, the nucleocapsid, containing partially-double stranded circular DNA, is generated. Assembly: HBsAg and the nucleocapsid containing partially double-stranded circular DNA are assembled together to become a new complete virion [39]. Release: The mature HBV virion (Dane particle) is released from the infected hepatocyte or is recycled back into the nucleus for amplification of cccDNA [38]. Other events: The $C$ gene directs the synthesis of two major gene products: $\mathrm{HBcAg}(\mathrm{p} 21 \mathrm{c})$, which comprises the nucleocapsid; and $\mathrm{HBeAg}(\mathrm{p} 17 \mathrm{e})$, which is a secreted antigen. Noninfectious particles (empty particles), which are composed of $\mathrm{HBsAg}$, a 22-kDa precore protein (p22cr), and $\mathrm{HBeAg}$, are also produced as a trap for the host immune system, in order to protect the infectious Dane particles. Serologic testing can assess $\mathrm{HBeAg}, \mathrm{p} 22 \mathrm{cr}$, and $\mathrm{HBcAg}$ as hepatitis B core-related antigen (HBcrAg). Abbreviations: HBV, hepatitis B virus; NTCP, sodium taurocholate cotransporting polypeptide; cccDNA, covalently closed circular DNA; RC-DNA, relaxed circular DNA; $\mathrm{HBsAg}$, hepatitis $\mathrm{B}$ virus surface antigen; $\mathrm{HBcAg}, \mathrm{HBV}$ core antigen; $\mathrm{HBV}$ e antigen, $\mathrm{HBeAg}$; $22 \mathrm{cr}$, precore protein; $\mathrm{HBcrAg}$, hepatitis B core-related antigen. 
into the nucleus to mediate viral persistence, or secreted as Dane particles through exocytosis to infect other hepatocytes [35] (Fig. 2) [37, 38, 39].

\section{EPIDEMIOLOGY: INCIDENCE AND PREVALENCE Incidence: worldwide view and HIV/HBV coinfection}

More than one third of the world's population are estimated to be infected with HBV. About $5 \%$ of the world's population are chronic carriers of HBV, and HBV infection causes more than one million deaths every year [40]. The HBsAg carrier rate varies from $0.1 \%$ to $20 \%$ of different populations worldwide. In low-risk regions, the highest incidence of infection is seen in teenagers and young adults.

Based on the data from Western cohorts, HIV/HBV coinfection has a profound impact on almost every aspect of the natural history of HBV infection [6]. The consequences include higher rates of chronicity after acute HBV infection, higher levels of HBV replication and rates of reactivation, less spontaneous clearance, higher rates of occult HBV infection (i.e., detectable HBV DNA positivity in the absence of HBsAg seropositivity), more rapid progression to cirrhosis and HCC, higher rates of liver-related mortality, and decreased treatment response compared with individuals without HIV coinfection [41, 42]. Recent longitudinal cohort studies have found that coinfection with $\mathrm{HBV}$ also can lead to increased rates of progression to acquired immune deficiency syndrome (AIDS)-related outcomes and all-cause mortality $[43,44]$. An estimated $5 \%$ to $15 \%$ of the 34 million HIV-infected individuals worldwide are coinfected with HBV, as a chronic infection $[45,46]$. The burden of coinfection is greatest in Southeast Asia and sub-Saharan Africa [6].

\section{Prevalence: international statistics}

An estimated 240 million people are chronically infected with hepatitis B [47]. The prevalence of chronic HBV infection varies geographically, ranging from $1 \%$ to $20 \%$. Populations with high rates include Alaskan Eskimos, AsianPacific islanders, Australian aborigines, and populations of the Indian subcontinent, sub-Saharan Africa, and Central Asia. In some locations, such as Vietnam, the rate is as high as $30 \%$ [48]. The prevalence of the HBV carrier state is related to differences in the mode of transmission, including iatrogenic transmission, and the age of primary infection.

In low-prevalence $(<2 \%)$ regions, the lifetime risk of HBV infection is less than 20\%. Sexual transmission and percutaneous transmission during early adulthood are the main routes of spreading the infection. About $12 \%$ of HBVinfected individuals live in the low-prevalence regions, which include North America, northern and western Europe, Australia, and New Zealand [48]. In these areas, most HBV infections occur in adolescents and young adults belonging to relatively well defined high-risk groups, which include injection drug users, MSM, healthcare workers, and patients who undergo regular blood transfusions or hemodialysis $[48,49]$.

In intermediate-prevalence (3\% - 5\%) regions, sexual and percutaneous transmission and vertical transmission during delivery are the major routes of infection. These regions include eastern and southern Europe, Japan, the Mediterranean basin, the Middle East, Latin and South America, and Central Asia. One study reported that approximately $43 \%$ of HBV-infected individuals live in southern, central, and western Asia; eastern Europe; Russia; and Central and South America. The lifetime risk of HBV infection is $20 \%-60 \%$ [48]. The persistently high rates of chronic infection are mostly due to infections occurring in infants and children.

In high-prevalence (10\% - 20\%) regions, transmission occurs predominantly in infants and children. During early childhood, HBV is transmitted vertically from the mother to infant or occurs via close contact. In some regions, percutaneous exposure to contaminated needles or an unsafe injection is also a possible route of HBV infection. Since most infections in children are asymptomatic, there is little evidence of acute HBV-related disease, but the rates of chronic liver disease and HCC in adults are high. Approximately $45 \%$ of individuals infected with HBV live in highprevalence regions. The lifetime risk of infection is higher than $60 \%$, as demonstrated by the presence of anti-HBc in sera [48]. The high-prevalence regions are mostly regions with developing economies and large populations. They include China, Southeast Asia, Indonesia, sub-Saharan Africa, the Pacific Islands, parts of the Middle East, and the Amazon Basin [48].

\section{HBV serotypes and genotypes}

Based on some of the antigenic determinants of $\mathrm{HBsAg}$, nine serological types - referred to as subtypesadw2, adw4, adrq+, adrq, ayw1, ayw2, ayw3, ayw4 and ayr have been identified [50]. Ten genotypes of HBV (A-J) have been identified, and these correspond to specific geographic distributions [51]. Genotype A is more frequently found in North America, northwestern Europe, India, and Africa. Genotypes B and C are endemic to Asia, and genotype $D$ predominates in eastern Europe and the Mediterranean [52]. Type $E$ is found in western Africa; type $F$, in South America; and type $G$, in France, Germany, Central America, Mexico, and the United States. Type $\mathrm{H}$ is prevalent in Central America [48]; type I, in Vietnam; and type J (possible recombination with type C), in Japan [53].

HIV-seropositive MSM populations predominantly coinfected with HBV genotype A have been reported in European countries and Japan $[54,55,56]$. The prevalence of HBV genotype A is significantly higher in the MSM population than in the rest of the population [56]. In addition, Araujo et al. speculated in their review that HBV subgenotypes $A 2$ and $C$ are likely to predominate in populations at high risk of infection via sexual transmission [57]. Additionally, HBV genotype A develops into a persistent infection more often than genotype $C[58,59]$.

Individuals infected with genotypes $\mathrm{C}$ and $\mathrm{F}$ have higher rates of HCC than individuals infected with genotypes $B$ and $D[6]$. Evidence increasingly suggests that genotype $C$ and $\mathrm{F}$ affect disease severity and response to treatment $[60,61,62]$. Results of studies in Asia suggest that patients infected by HBV genotype $\mathrm{C}$ show a more rapid progression 
TABLE 2. Scheuer classification for grading and staging of chronic hepatitis [72].

\begin{tabular}{c|l|l}
\hline Grade & \multicolumn{1}{|c}{ Portal / periportal activity } & \multicolumn{1}{|c}{ Lobular activity } \\
\hline 0 & None & None \\
\hline 1 & Portal inflammation & Inflammation but no necrosis \\
\hline 2 & Mild piecemeal necrosis & Focal necrosis or acidophil bodies \\
\hline 3 & Moderate piecemeal necrosis & Severe focal cell damage \\
\hline 4 & Severe piecemeal necrosis & Damage includes bridging necrosis \\
\hline 0 & & None \\
\hline 1 & Enlarged, fibrotic portal tracts & \\
\hline 2 & Periportal or portal-portal septa, but intact architecture \\
\hline 3 & Fibrosis with architectural distortion, but no obvious cirrhosis \\
\hline 4 & Probable or definite cirrhosis & \\
\hline
\end{tabular}

to cirrhosis and HCC than patients infected by genotype B $[63,64,65]$, and subgenotypes of HBV genotype $C$ are probably responsible for the increased rate of $\mathrm{HCC}$ in patients who were positive for $\mathrm{HBeAg}$ [66]. Studies in Europe and North America have found that higher proportions of patients with chronic hepatitis associated with genotype $D$ infection progressed to cirrhosis and HCC than those with chronic hepatitis associated with genotype A infection [26, $67,68,69]$.

\section{PATHOPHYSIOLOGY / SEROLOGY / SIGNS AND SYMP- TOMS}

\section{Pathophysiology}

\section{Pathological findings}

Currently, most liver biopsies are performed to confirm the existence of chronic hepatitis and to determine its level of activity. This section mainly describes chronic hepatitis, which plays an important role in HBV infection.

\section{1) Acute hepatitis $B$}

Because acute hepatitis $B$ is always diagnosed by clinical symptoms and serologic markers related to HBV infection, liver biopsies are not often performed. In general, acute hepatitis shows more areas of spotty parenchymal inflammation and more severe damage than typical chronic hepatitis. The lesions mainly contain diffuse sinusoidal and portal mononuclear infiltrates (lymphocytes, plasma cells, Kupffer cells), swollen hepatocytes and/or necrotic hepatocytes (also called apoptotic or acidophilic hepatocytes, or Councilman bodies) $[70,71]$. Cell plates and sinusoids may be indistinct in more severe cases as a result of hepatocyte swelling, filling of sinusoids by mononuclear inflammatory cells, and regenerating hepatocytes. Significant lobular necrosis leads to acute liver failure [70].

\section{2) Chronic hepatitis B and cirrhosis}

In chronic HBV infection, there is a varying degree of predominantly lymphocytic portal inflammation with interface hepatitis and spotty lobular inflammation. The inflammation is minimal in the immune-tolerant or inactive chronic infection stages, but is prominent in the immune-active stage. Bridging necrosis is identified as inflammation "connecting" portal tracts to one another or to central veins [71]. Confluent necrosis affects multiple contiguous hepatocytes. Inflammation is typically associated with scarring, which can vary from a mild portal extension to periportal fibrous strands, bridging fibrosis, and cirrhosis. Livers that develop central to portal bridging necrosis or confluent necrosis are likely to have a higher fibrosis stage. The Scheuer classification for grading and staging of chronic hepatitis is often used, as shown in Table 2 [72].

The hepatocytes that express a high level of HBsAg may have a "ground-glass" cytoplasm, which can be highlighted by special immunohistochemical stains (Shikata's orcein and Victoria blue). Ground-glass hepatocytes may also be seen in other conditions [73].

Cirrhosis is diagnosed when the loss of normal centralportal relationships is observed. The atypical enlargement of nuclei with an increase in the nuclear-cytoplasmic ratio, known as "large cell change", is very common in cirrhosis. This cytologic abnormality should only be used to support the evidence of regeneration and architectural abnormalities, which is used for diagnosing cirrhosis [70]. 
TABLE 3. Interpretation of results of serologic tests for HBV infection [2].

\begin{tabular}{c|c|c|c|l}
\hline \multicolumn{7}{|c}{ Serologic marker } & \multicolumn{2}{l}{} \\
\hline HBsAg & Total anti-HBc & IgM anti-HBc & Anti-HBs & \\
\hline- & - & - & - & Never infected \\
\hline+ & - & - & - & $\begin{array}{l}\text { Early acute infection, transient (up to 18 days) after vac- } \\
\text { cination }\end{array}$ \\
\hline+ & + & + & - & Acute infection \\
\hline- & + & + & - & Acute resolving infection \\
\hline+ & + & - & + & Recovered from past infection and immune \\
\hline- & + & - & - & \begin{tabular}{l} 
Chronic infection \\
\hline+
\end{tabular} \\
\hline+ & + & - & $\begin{array}{l}\text { False positive (i.e., susceptible), previous infection, “low- } \\
\text { level” chronic infection, passive transfer to infant born to } \\
\text { HBsAg-positive mother }\end{array}$ \\
\hline
\end{tabular}

Symbol for negative test result, "_"; symbol for positive test result, "+."

Abbreviations: $\mathrm{HBV}$, hepatitis B virus; $\mathrm{HBsAg}$, hepatitis B surface antigen; anti-HBc, antibody to hepatitis B core antigen, IgM anti-HBc, immunoglobulin $M$ antibody to hepatitis B core antigen; HBIG, hepatitis B immune globulin.

\section{Diagnosis}

Serologic markers related to HBV infection

The serologic markers of HBV infection are as follows: $\mathrm{HBsAg}$ and the corresponding antibody anti-HBs, $\mathrm{HBeAg}$ and the corresponding antibody anti-HBe, immunoglobulin $\mathrm{M}$ antibody to hepatitis $B$ core antigen (IgM anti-HBC), immunoglobulin $G$ antibody to hepatitis $B$ core antigen (IgG anti-HBC), and serum HBV DNA. The diagnosis of acute or chronic HBV infection requires serologic testing (Table 3) [2]. The first detectable markers in acute HBV infection are $\mathrm{HBsAg}$ and IgM anti-HBc.

Total anti-HBc is present over the entire lifetime of the infected individual. It is found in individuals with chronic HBV infection and in those who recover from HBV infection [10]. The presence of anti-HBc alone might indicate acute, resolved, or chronic infection, or a false-positive result [2]. $\mathrm{HBsAg}$ and $\mathrm{HBeAg}$ can be used as surrogate markers of HBV replication [74]. HBsAg is eliminated from the sera of individuals who recover from HBV infection, and anti-HBs is detectable during recovery [10]. Detection of $\mathrm{HBsAg}$ indicates early acute infection. To ensure that an HBsAgpositive test result is not false positive, samples with repeatedly reactive $\mathrm{HBsAg}$ results should be tested with a US Food and Drug Administration (FDA)-cleared neutralizing confirmatory test [2]. HBeAg is a marker of high levels of viral replication. Detection of $\mathrm{HBeAg}$ indicates that the blood and body fluids of an infected person are highly infectious. Detection of anti-HBeAg indicates inactive chronic hepatitis. The persistence of $\mathrm{HBeAg}$ for longer than 10 weeks and/or HBsAg and serum HBV DNA for longer than 6 months, indicates transition to chronic HBV infection [74]. Detection of anti-HBs indicates immunity against HBV. An-
ti-HBs can also be detected in individuals who were immunized by the HB vaccine. Most individuals who recover from HBV infection are expected to be positive for both anti-HBs and anti-HBC [10]. Individuals positive for anti-HBC only are unlikely to be infectious, except under unusual circumstances, including direct percutaneous exposure to large quantities of blood (e.g., blood transfusion and organ transplantation) from individuals positive for anti-HBC only [2].

\section{Acute hepatitis $B$}

The incubation period (duration from exposure to HBV to onset of symptoms) of HBV-infected individuals with acute hepatitis ranges from 60 to 150 days, with an average of 90 days $[75,76]$. The signs and symptoms of acute hepatitis $B$ are described in detail in the "Signs and symptoms" section. As mentioned previously, the clinical manifestations of acute HBV infection are age dependent [10]. Over $90 \%$ of infants with HBV infection are asymptomatic, while the typical manifestations of acute hepatitis are prominent in $5 \%$ to $15 \%$ of newly infected young children (aged 1-5 years) and in 33\% to $50 \%$ of children older than 6 years of age $[10,21]$. Serologic markers related to acute hepatitis $B$ are described in the subsection "Serologic markers related to HBV infection". As described in that subsection, the persistence of $\mathrm{HBeAg}$ indicates the transition to chronic HBV infection [74].

\section{Chronic HBV infection}

The natural history of HBV infection, including the transition to chronic infection, is described in the "Etiology" section. Chronic HBV infection is defined as either the pres- 
ence of HBsAg in the serum for at least 6 months or the presence of $\mathrm{HBsAg}$ in a person who tests negative for IgM anti-HBc [10]. Unlike individuals who recover from acute HBV infection, patients with chronic HBV infection do not produce anti-HBs, and serum HBsAg positivity typically persists for a long period of time [10]. In patients with chronic HBV infection, the disappearance of $\mathrm{HBeAg}$ and detection of anti-HBe usually indicate a reduction in viral load [77]. Each year, approximately $0.5 \%$ of adults with chronic HBV infection will clear HBsAg and produce antiHBs $[78,79,80]$. Although patients with chronic HBV infection die of causes unrelated to HBV, chronic HBV infection is responsible for most of the morbidity associated with HBV [10]. Follow-up studies of individuals first infected with HBV when they were infants or young children, show that approximately $15 \%$ to $25 \%$ of patients with chronic infection die prematurely from cirrhosis or $\operatorname{HCC}[81,82]$.

\section{Signs and symptoms}

\section{Symptoms and physical findings}

The manifestations of HBV infection during the acute phase vary from subclinical hepatitis to acute hepatitis and acute hepatic failure. During the chronic phase, disease progression varies from asymptomatic chronic infection to chronic hepatitis, cirrhosis, and HCC [83]. The findings on physical examination vary from minimal to remarkable, according to disease severity. The signs, symptoms, and findings on physical examination are listed in Table 4.

Acute hepatitis B is an illness that begins with general fatigue, loss of appetite, nausea, vomiting, body aches, low-grade fever, dark urine, and jaundice. The illness lasts for several weeks and then gradually improves in most affected individuals. A few individuals may develop more severe liver disease (acute hepatic failure) and may die. In addition, acute hepatitis $B$ infection may be entirely asymptomatic and may go unrecognized [84].

Some acute hepatitis $B$ patients (about 1\%) may devel- op acute liver failure, which is characterized by evidence of decompensated liver disease and is fatal in up to $50 \%$ of cases [83]. Patients with acute liver failure can present with the following signs and symptoms: hepatic encephalopathy, somnolence, disturbed sleep patterns, mental confusion, coma, ascites, variceal bleeding, and coagulopathy.

Individuals with chronic HBV infection may be asymptomatic or may manifest the signs and symptoms associated with chronic hepatic inflammation. Patients with chronic active hepatitis, especially during the replicative stage, can manifest symptoms similar to acute hepatitis (fatigue, anorexia, nausea, and mild upper quadrant pain or discomfort). Physical examination of patients with chronic HBV infection can reveal the typical characteristics of chronic liver disease, including hepatomegaly, splenomegaly, muscle wasting, palmar erythema, spider angioma, and vasculitis.

In cases with progressive liver disease, the following manifestations may be present: hepatic decompensation, hepatic encephalopathy, somnolence, disturbed sleep patterns, mental confusion, coma, ascites, variceal bleeding, coagulopathy, ascites, jaundice, peripheral edema, gynecomastia, testicular atrophy, and collateral abdominal veins (caput medusa). Pleural effusion and hepatopulmonary and portopulmonary syndrome may occur in patients with cirrhosis. Patients with cirrhosis may have the following findings: ascites, jaundice, history of variceal bleeding peripheral edema, gynecomastia, testicular atrophy, and collateral abdominal veins.

\section{Extrahepatic manifestations}

Extrahepatic manifestations of HBV infection occur in 1\% to $10 \%$ of patients, and include serum-sickness-like syndrome, acute necrotizing vasculitis (polyarteritis nodosa), membranous glomerulonephritis (MGN)[85], and papular acrodermatitis of childhood (Gianotti-Crosti syndrome)

TABLE 4. Manifestations of hepatitis B virus infection.

\begin{tabular}{l|l}
\hline \multicolumn{1}{c|}{ Clinical staging } & \multicolumn{1}{c}{ Signs, symptoms, and clinical findings } \\
\hline Acute hepatitis & $\begin{array}{l}\text { General fatigue, loss of appetite, nausea, vomiting, abdominal pain, low-grade fever, jaun- } \\
\text { dice, hepatomegaly, splenomegaly, palmar erythema, spider nevi, Gianotti-Crosti syndrome } \\
\text { (papular acrodermatitis), serum-sickness-like syndrome, necrotizing vasculitis (polyarteritis } \\
\text { nodosa), membranous glomerulonephritis (MGN), cryoglobulinemia, aplastic anemia, transi- } \\
\text { ent maculopapular rash. }\end{array}$
\end{tabular}

Chronic hepatitis

Similar to acute hepatitis, (hepatomegaly, splenomegaly, muscle wasting, palmar erythema, spider angioma, vasculitis).

Progressive liver disease, including hepatic decompensation
Ascites, jaundice, history of variceal bleeding, peripheral edema, gynecomastia, testicular atrophy, abdominal collateral veins (caput medusa), hepatic encephalopathy, somnolence, disturbances in sleep patterns, mental confusion, coma, variceal bleeding, coagulopathy, pleural effusion, hepatopulmonary, and portopulmonary syndrome.

Acute liver failure

Ascites, fever, jaundice, hepatomegaly, splenomegaly, hepatic encephalopathy, somnolence, disturbances in sleep pattern, mental confusion, coma, variceral bleeding, coagulopathy. 
$[86,87]$. Serum-sickness-like syndrome occurs in the setting of acute hepatitis $B$, often preceding the onset of jaundice [88]. The manifestations often subside shortly after the onset of jaundice, but can persist throughout the duration of acute hepatitis B [11]. About $30 \%$ to $50 \%$ of people with acute necrotizing vasculitis (polyarteritis nodosa) are HBV carriers [89]. HBV-associated nephropathy has been described in adults but is more common in children [90, 91]. MGN is the most common form. Other immune-mediated hematological disorders, such as essential mixed cryoglobulinemia and aplastic anemia, can also occur [11].

A variety of cutaneous lesions can appear during the early course of viral hepatitis, including transient maculopapular rash.

\section{TRANSMISSION AND PROTECTION}

\section{Transmission}

As described previously, HBV is transmitted mainly via percutaneous or permucosal exposure to HBV-containing body fluids. The most critical source of infection is blood (serum) [92]. HBV transmission has been found to occur through various forms of human contact, including vertical transmission from mother to newborn, sexual contact, close household contact, needle sharing, and occupational (healthcare) exposure (horizontal transmission) [10]. HBV transmission can result from the accidental inoculation of small amounts of blood or other body fluids during medical procedures [6]. Nowadays, blood transfusion and organ transplantation are extremely rare routes for HBV transmission. This section will primarily focus on sexual transmission, which is a common route of HBV infection.

HBV is efficiently transmitted by sexual contact [10]. The primary risk factors are unprotected sex with an HBVinfected partner, mainly unvaccinated MSM and heterosexual individuals with multiple sex partners or contact with sex workers [6]. MSM have long been known to have high rates of STIs [93]. They continue to show higher seroprevalence rates of HBV-related markers than the general population [94]. Progression through the infection stages is very rapid, and the immune tolerant stage is sometimes absent $[24,95]$.

Heterosexual transmission is still important, as shown by the $40 \%$ transmission rate to nonimmune partners of patients with acute HBV hepatitis or chronic HBV infection $[96,97]$. The seroprevalence rates of HBV-related markers are positively correlated with increasing numbers of current and lifetime heterosexual partners [98, 99].

\section{Protection}

Behavioral approaches

The 2015 Centers for Disease Control and Prevention (CDC) guidelines describe five major strategies for the prevention and control of STIs (Table 5) [100]. For primary prevention, the first approach is to change the sexual behavior that can increase the risk of STIs. Information on sexual behavior that can increase the risk of STIs should be provided tactfully. In addition, adolescents and young adults should be made aware that some of the information on protection against STIs may be inaccurate [100]. Correcting misinformation on protection against STIs may also reduce the incidence of high-risk sexual behavior[101]. One of the most reliable methods for preventing an STI is refraining from sexual contact, which includes oral, vaginal, and anal sex [100].

Over the past 10 years, condom use by unprotected heterosexuals has increased in the United States, suggesting that information on the prevention of STIs is being widely disseminated and understood [102]. Additionally, possible sexual partners should be tested for STIs before sexual contact is initiated [100]. If one partner has an STI or his/her infection status is unknown, a new condom should be used for each sexual contact.

In summary, safe sex practices, including minimizing the number of sex partners and using barrier protection, can reduce the risk of HBV infection.

Hepatitis $B$ immune globulin (HBIG) and hepatitis $B(H B)$ vaccine

Both HBIG and $\mathrm{HB}$ vaccines have been approved for preventing HBV infection $[103,104]$.

$\mathrm{HBIG}$ is prepared from human plasma containing a high concentration of anti-HBs and provides short-term ( 3 to 6 months) protection from HBV infection. It is typically used as post-exposure prophylaxis along with $\mathrm{HB}$ vaccination for

TABLE 5. Major strategies for prevention and control of STIs [100].

Major strategies for prevention and control of STIs.

1. Accurate risk assessment and education and counseling of individuals at risk on ways to avoid STIs through changes in sexual behavior and use of recommended devices of prevention;

2. Pre-exposure vaccination of individuals at risk for vaccine-preventable STIs;

3. Identification of asymptomatically infected individuals and individuals with symptoms associated with STIs;

4. Effective diagnosis, treatment, counseling, and follow up of infected individuals;

5. Evaluation, treatment, and counseling of sex partners of individuals who are infected with an STI.

Abbreviation: STIs, sexually transmitted infections. 
individuals who have never been vaccinated or who have not responded to $\mathrm{HB}$ vaccination. The recommended dose of $\mathrm{HBIG}$ is $0.06 \mathrm{~mL} / \mathrm{kg}$ [100].

$\mathrm{HB}$ vaccines contain $\mathrm{HBsAg}$ that is produced by a recombinant yeast strain [105]. Epidemiologic studies have not found any evidence of an underlying association between $\mathrm{HB}$ vaccination and sudden infant death syndrome or other causes of death during the first year of life $[106,107]$. Thus, HB vaccination can be considered safe.

$H B$ vaccination is the most effective method of preventing HBV infection [108]. The introduction of universal $H B$ vaccination for newborns has been reported to be a very reasonable and cost-effective strategy $[109,110]$. The World Health Organization (WHO) has now included HB vaccination in the Expanded Program on Immunization [22]. WHO recommends that all infants receive $\mathrm{HB}$ vaccine as soon as possible after birth, preferably within 24 hours. In 2013, 183 WHO member states immunized infants against $\mathrm{HBV}$ as a part of their routine vaccination schedule, and $81 \%$ of children received $H B$ vaccines [47].

$H B$ vaccine is available for younger children, adolescents, and healthy adults [2]. In adolescents and healthy adults (aged younger than 40 years), approximately $30 \%$ to $55 \%$ of recipients achieve protective antibody responses (i.e., anti-HBs $\geq 10 \mathrm{mlU} / \mathrm{mL}$ ) after the first vaccination, $75 \%$ after the second, and over $90 \%$ after the third. Therefore, $H B$ vaccination can be thought to induce protective antibody response (anti-HBs $\geq 10 \mathrm{mlU} / \mathrm{mL}$ ) in the majority of recipients. Regardless of the specific patient considerations needed when an HB vaccination schedule is selected, a complete vaccine series should be administered[100]. Recommendations on the $\mathrm{HB}$ vaccine dosage and schedule vary, depending on the product used and the recipient's age [2]. Details on HB vaccination are described in guidelines $[6,104]$.

$H B$ vaccine-induced immune memory has been established to last for more than 20 years [111, 112, 113]. According to the 2015 CDC guidelines, periodic monitoring of anti-HBs levels after routine $\mathrm{HB}$ vaccination is not needed, and booster doses of $\mathrm{HB}$ vaccine are not currently recommended [2]. However, the American Red Cross report suggests that HB-vaccine-induced immune memory might be limited; although HB vaccination can prevent clinical liver injury (hepatitis), $100 \%$ of subclinical infections cannot be prevented [114]. Indeed, although HB vaccine is sufficiently effective at preventing the development of clinical disease (hepatitis), it cannot prevent $100 \%$ of HBV infections, resulting in detectable anti-HBc [114]. Additionally, there is a report of acute hepatitis $B$ infection in a patient who received five $H B$ vaccinations [115]. An MSM patient, who received several $H B$ vaccinations and showed an anti-HBs serological response of $>10 \mathrm{mlU} / \mathrm{mL}$ (accepted threshold for protection), was reported to have developed a chronic HBV genotype $F$ infection [116]. These cases suggest that monitoring anti-HBs levels after routine vaccination might be necessary for certain patients. When the anti-HBs level is too low to provide protection from HBV infection (anti$\mathrm{HBs}<10 \mathrm{mlU} / \mathrm{mL}$ ), a booster vaccination should be administered. Although HB vaccines are highly immunogenic, postvaccination serologic testing might be indicated for infants whose mothers were infected at delivery, individuals with occupational exposure to blood, sexually active individuals such as MSM, or immunosuppressed individuals [10].

\section{Pre-exposure vaccination}

In 1992, WHO recommended that all countries should introduce universal $\mathrm{HB}$ vaccination into their routine immunization programs [117]. HB vaccination is recommended for all unvaccinated children and adolescents, all unvaccinated adults with risk of HBV infection (especially MSM, adults with multiple sex partners, and drug users), and all adults desiring protection from HBV infection [104]. HB vaccine should be routinely offered to all unvaccinated persons who attend STI clinics or seek evaluation or treatment for STIs in other settings, especially correctional facilities, facilities providing treatment and prevention services for substance use disorder, and settings serving MSM (e.g., HIV care and prevention settings) [2].

\section{Postexposure prophylaxis}

Both passive-active postexposure prophylaxis (simultaneous administration of $\mathrm{HBIG}$ and $\mathrm{HB}$ vaccine at separate sites) and active postexposure prophylaxis (administration of $\mathrm{HB}$ vaccination alone) have been demonstrated to be highly effective for preventing HBV infection [103]. Unvaccinated individuals or those known not to have received a complete HB vaccine series should receive both HBIG and $H B$ vaccine as soon as possible (preferably $\leq 24$ hours) after exposure to blood or body fluids containing $\mathrm{HBsAg}$. HB vaccine should be administered at the same time as HBIG but at a separate injection site; and the HB vaccine series should be completed, using the age-appropriate vaccine dose and schedule [2]. Individuals with certification that they received a complete $\mathrm{HB}$ vaccine series and who have never undergone post-vaccination serologic testing should receive a single vaccine booster dose. These individuals should be treated according to guidelines for the management of individuals with occupational exposure to blood or body fluids that contain HBV [118].

\section{TREATMENT AND CURABILITY \\ Treatment}

The primary treatment goals for patients with HBV infection are preventing the progression to severe liver disease. The prevention of cirrhosis, hepatic failure, and HCC are most important. The risk factors for progression of chronic $\mathrm{HBV}$ include male gender, older age, family history of HCC, elevated alpha-fetoprotein (AFP) level, and coinfection with other viruses (HCV, HDV, or HIV) [119].

For the best outcome, a synergistic approach that decreases the viral load and uses immunotherapeutic interventions to boost the immune response is needed [120]. The prevention of $\mathrm{HCC}$ often includes antiviral treatment using pegylated interferon (PEG-IFN) or nucleos(t)ide analogues (NAs), which are described later [121]. 


\section{Overall management for types of HBV infection}

Patients with acute hepatitis B are treated by supportive care, with no specific treatment. Patient care is focused on maintaining comfort and adequate nutritional balance, including replacement of fluids lost from vomiting and diarrhea. Patients with chronic HBV infection should be referred for evaluation to a provider experienced in the management of chronic HBV infection [122]. A variety of treatment algorithms have been proposed, including ones from the American Association for the Study of Liver Diseases (AASLD) [28], the European Association for the Study of the Liver (EASL) [23], the Asian Pacific Association for the Study of the Liver (APASL) [123], the Canadian Association for the Study of the Liver (CASL) [124], and the National Institute for Health and Clinical Excellence (NICE) [125].

In general, for patients with chronic HBV infection who are positive for serum $\mathrm{HBeAg}$, treatment is advised when the serum level of HBV DNA is at or greater than 20,000 $\mathrm{IU} / \mathrm{mL}\left(10^{5}\right.$ copies $/ \mathrm{mL}$ ) (or $>2,000 \mathrm{IU} / \mathrm{mL}$ [EASL recommendation]) and the serum ALT level is elevated ( $>20 \mathrm{U} / \mathrm{L}$ for females and $30 \mathrm{U} / \mathrm{L}$ for males) for 3-6 months. For patients with chronic $\mathrm{HBV}$ infection who are negative for $\mathrm{HBeAg}$, treatment is advised when the serum level of HBV DNA is at or greater than $2,000 \mathrm{IU} / \mathrm{mL}\left(10^{4}\right.$ copies $\left./ \mathrm{mL}\right)$ and the serum ALT is elevated ( $>20 \mathrm{U} / \mathrm{L}$ for females and $30 \mathrm{U} / \mathrm{L}$ for males) for 3-6 months [126].

Treatment of HIV infection with nucleos(t)ide analogs active against HBV greatly improves the outcomes of hepatic disease, including cirrhosis and HCC, in HIV-HBV coinfected patients, especially when tenofovir is part of the antiviral regimen [127]. HBV/HDV coinfection should be treated with PEG-IFN therapy [128].

The National Institutes of Health (NIH) also advises that immediate therapy is not usually indicated for the following patients: 1) patients who are in the immune-tolerant stage, with chronic hepatitis $B$ and high serum levels of HBV DNA but normal serum ALT levels or little activity on liver biopsy; 2) patients who are in an inactive chronically infected/low replicative stage and have low serum levels of or undetectable HBV DNA and normal serum ALT levels; and 3) patients who are not immunosuppressed and have latent HBV infection, defined as detection of HBV DNA in the absence of HBsAg [126].

\section{Pharmacologic management}

The therapeutic agents cleared by FDA for the treatment of chronic hepatitis $B$ can achieve sustained suppression of $\mathrm{HBV}$ replication and remission of liver disease [122]. Currently, PEG-IFN- $\alpha 2 a$, entecavir, and tenofovir are available for the treatment of HBV infection. These are the main treatments that have been approved worldwide. Lamivudine, telbivudine, and adefovir are now "nonpreferred" agents, and considered to be of historical interest [129].

\section{Pegylated interferon alpha 2a (PEG-IFN- $\alpha$ 2a)}

IFNs are naturally produced cytokines. They induce direct antiviral activity by stimulating the host's antiviral immune response and mediating conflicting effects on viral replication. PEG-IFN- $\alpha 2$ a has a longer half-life and enhanced effi- cacy relative to standard IFN- $\alpha$. Pegylation lowers the rate of absorption following subcutaneous injection, reduces renal clearance, and decreases the immunogenicity of IFN [130].

The advantages of IFN therapy are the absence of viral resistance, the finite course of treatment (normally 48 weeks), an increased chance of sustained virological response (SVR), and HBeAg and HBsAg clearance; compared with patients treated by NAs [131]. A 48-week regimen of PEG-IFN- $\alpha 2$ a has been found to induce $\mathrm{HBeAg}$ seroconversion in $27 \%$ of patients and disappearance of serum HBV DNA in $25 \%$ of patients [130]. Long-term studies have demonstrated that IFN treatment is associated with a significant reduction in the risk of cirrhosis and HCC, even in patients who fail to clear HBeAg [24]. However, IFN has a poor side-effect profile (including persistent flu-like symptoms and psychiatric complications) compared with NAs, requires subcutaneous injection, and is not recommended for patients with decompensated cirrhosis [25]. HBV genotypes $A$ and $D$ are important and independent predictors of IFN responsiveness in patients with chronic hepatitis $B$ [132]. IFN treatment is more effective for patients who are most likely to benefit, especially younger patients, who have more potential years in which to develop complications from their chronic hepatitis B infection and thus have more to gain from achieving an SVR $[25,95]$.

\section{Nucleos(t)ide analogues (NAs)}

The NIH recommends nucleos(t)ide therapy for the treatment of HBV-infected patients with acute liver failure as well as for cirrhotic patients who are positive for serum HBV DNA; and for patients with clinical complications, cirrhosis, advanced fibrosis with serum positive for HBV DNA, or reactivation of chronic HBV during or after chemotherapy or immunosuppression [126].

Entecavir, a guanosine nucleoside analogue, is a firstline agent for the treatment of HBV infection [51]. It is a powerful inhibitor of HBV polymerase. It competes with the natural substrate, deoxyguanosine triphosphate (dGTP), to inhibit HBV polymerase (reverse transcriptase) activity. The advantages of therapy with this agent include potent antiviral activity and a low rate of resistance to the drug [51], although entecavir is used less frequently than other agents for the treatment of lamivudine-resistant HBV.

Results of a retrospective study indicated that assessment of serum HBV DNA levels 12 months after initiation of entecavir therapy may be useful for evaluating entecavir therapy for NA-naïve, HBV-infected patients [7]. Investigators found 3 independent predictors for viral suppression lasting 3 years after the start of entecavir therapy: the lowest level of HBV DNA that can be detected, undetectable serum HBV DNA at month 12, and seronegative for $\mathrm{HBeAg}$ at the start of therapy. Serum HBV DNA undetectable at month 12 also increased the probability of $\mathrm{HBeAg}$ seroconversion and lowered the risk of drug resistance [133].

In another study, after 240 weeks of continuous entecavir therapy for HBeAg-positive patients, $94 \%$ of pa- 
tients had less than 300 copies/mL of serum HBV DNA, and $80 \%$ had normal ALT levels. An additional $23 \%$ of patients achieved $\mathrm{HBeAg}$ seroconversion, and $\mathrm{HBsAg}$ disappeared in $1.4 \%$ of the patients. Only 1 patient developed resistance to treatment with entecavir within 5 years of treatment [134].

Another study found that long-term treatment with entecavir (about 6 years of cumulative therapy [range, 267297 weeks]) for NA-naïve patients with chronic HBV infection and advanced fibrosis or cirrhosis, resulted in durable virologic suppression, continued histologic improvement, and reversal of fibrosis or cirrhosis [135].

Tenofovir is the newest antiviral agent. It is a nucleotide-analogue (adenosine monophosphate) inhibitor of viral reverse transcriptase. It may be used as first-line therapy for treatment-naïve patients [51]. Patients who received tenofovir continuously for 240 weeks had sustained suppression of serum HBV DNA levels (less than 400 copies $/ \mathrm{mL}$ ). The rate of viral suppression in patients negative for $\mathrm{HBeAg}$ was $83 \%$, and in patients positive for $\mathrm{HBeAg}$ was $65 \%$. Of the patients positive for $\mathrm{HBeAg}$ who received tenofovir through 240 weeks, the rate of disappearance of $\mathrm{HBsAg}$ was $9 \%$, and the $\mathrm{HBsAg}$ seroconversion rate was $7 \%$. The rate of disappearance of $\mathrm{HBeAg}$ was $46 \%$, and the $\mathrm{HBeAg}$ seroconversion rate was $40 \%$. There was no evidence of resistance to tenofovir over the treatment period [125]. Of note, follow up of the same cohort revealed that after 4.5 years of tenofovir, $87 \%$ had histological improvement, $51 \%$ had regression of fibrosis, and $74 \%$ of the patients with cirrhosis at baseline were no longer cirrhotic [136].

\section{Monitoring considerations}

The tests that should be used and the frequency of testing will depend on the patient's serological profile (HBeAgpositive or -negative) and HBV DNA viral levels [126]. Patients with chronic active hepatitis should undergo blood testing (aminotransferase levels, HBV status, viral load, and AFP levels), as well as treatment.

For individuals with inactive chronic HBV infection, the current guidelines recommend monitoring for serum HBV DNA and ALT levels at least annually [23,28, 137]. Patients with cirrhosis must be monitored for $\mathrm{HCC}$ by determination of AFP levels every 6 to 12 months and undergoing surveillance by abdominal ultrasonography $[28,137]$. Note, however, that determination of AFP levels was excluded from the AASLD guidelines [28].

\section{Curability}

Despite notable progress regarding many aspects of HBV infection, particularly with respect to prevention and treatment, chronic HBV infection remains strictly noncurable, because residual HBV cccDNA can always be detected in the liver, even after clearance of $\mathrm{HBsAg}$ and development of anti-HBs in the serum [138]. Moreover, HBV DNA sequences can integrate into the hepatocyte genome, as demonstrated in individuals seronegative for HBsAg [139]. Therefore, the term "cure" cannot be used to indicate that HBV is completely eradicated.
There is ongoing discussion on the meaning of "'cured' of chronic HBV infection". The primary treatment goal for $\mathrm{HBV}$ infection is to improve patient quality of life and reduce the risk of death from liver disease [140]. Large cohort studies of patients with chronic hepatitis $B$ have found a $15 \%$ to $40 \%$ cumulative risk of developing cirrhosis. Two to five percent of patients with established cirrhosis will develop HCC [141]. Three possible types of cure are identified, which are described below [140].

"Absolute cure" means that the patient is free of HBV. That is, there are no $\mathrm{HB}$ virions and cccDNA anywhere in the body, including hepatocytes. The patient recovers to the degree of health and medical condition prior to HBV infection, and the probability of developing cirrhosis or HCC depends on age and gender. Although this type of cure is uncommon, it is the most desirable [140].

"Functional cure" means that HBV progression can be controlled. The patient recovers to his or her state of health equal to that of a person who has recovered spontaneously from HBV infection. Both have a similar likelihood of developing cirrhosis or HCC. Current therapy can only achieve "functional cure" through suppression of HBV replication [140].

"Apparent virologic cure" is defined as a sustained offdrug suppression of virologic markers and the normalization of liver function. This last definition includes an SVR, which is the ongoing suppression of viral load following the cessation of therapy, and adds the disappearance of all circulating viral markers (seroclearance), and the possible suppression of cccDNA. A complicating factor with HBV infection is that patients who have achieved a serologic resolution of infection (loss of $\mathrm{HBsAg}$, undetectable serum HBV DNA, appearance of anti-HBs) can develop reactivation of their disease because of immunosuppression or the use of anti-inflammatory medications [142, 143]. In addition, it is important to note that in occult HBV infection, despite the complete loss of $\mathrm{HBsAg}$ and undetectable or very low levels of HBV DNA in serum, there may still be an increased risk for progression to cirrhosis and the development of HCC [144].

An "apparent virologic cure" or "functional cure" as a desirable endpoint for therapy is supported by a recent study looking at the risk of HCC in patients with or without spontaneous seroclearance of HBV seromarkers [145]. However, none of these endpoints turned out to be a reliable indicator of favorable long-term outcome of chronic $\mathrm{HBV}$ infection. Thus, for the time being, HBsAg loss is viewed as the best possible predictor of a favorable longterm outcome of HBV infection and is used as an endpoint $[146,147]$.

\section{CONCLUSIONS}

HBV infection is one of the common STIs having a major worldwide impact on a patient's clinical health status and on public health, and is also associated with liver-related morbidity and mortality. New HBV infections in industrialized countries are becoming increasingly concentrated among individuals at risk for STIs, infants, and injection 
drug users. $\mathrm{HB}$ vaccines have been an effective prevention strategy for individuals at risk through sexual exposure, especially MSM and heterosexuals with multiple sex partners. The proper education of persons at risk for STIs may also help with their acceptance of $\mathrm{HB}$ vaccination.

Regarding the persistence of $\mathrm{HB}$ vaccine-induced immunity, the effectiveness of routine $\mathrm{HB}$ vaccination might not last long enough to prevent $100 \%$ of HBV infections. In our opinion, postvaccination serologic testing, especially for anti-HBs, should be introduced for groups at high risk for HBV infection, after careful consideration. Potential causes of vaccine failure, such as infection with HBV variants, require further study. The need for booster doses to preserve vaccine-induced immunity should be evaluated regularly, especially for infants whose mothers were infected, individuals with occupational risk, sexually active individuals such as MSM, or individuals under immunosuppression.

\section{REFERENCES}

1. World Health Organization (2015). Sexually transmitted infections (STIs), Available: http://www.who.int/mediacentre/factsheets/fs110/en/. Accessed: 29.04.2016.

2. Workowski KA, Bolan GA (2015). Sexually transmitted diseases treatment guidelines, 2015. MMWR Recomm $\operatorname{Rep} 64(\operatorname{Rr}-03)$ : 1-137.

3. ASHA, (2016). STDs/STIs, Available: http://www.ashasexualhealth.org/stdsstis . Accessed: 29.04.2016.

4. Handsfield $\mathrm{HH}$ (2005). Hepatitis A and B immunization in persons being evaluated for sexually transmitted diseases. Am J Med 118 Suppl 10A(69s-74s).

5. Remis RS, Dufour A, Alary M, Vincelette J, Otis J, Masse B, Turmel B, LeClerc R, Parent R, Lavoie R (2000). Association of hepatitis $B$ virus infection with other sexually transmitted infections in homosexual men. Omega Study Group. Am J Public Health 90(10): 1570-1574.

6. WHO Guidelines Approved by the Guidelines Review Committee (2015). Guidelines for the Prevention, Care and Treatment of Persons with Chronic Hepatitis B Infection. World Health Organization Copyright (c) World Health Organization 2015., Geneva.

7. Chang TT, Gish RG, de Man R, Gadano A, Sollano J, Chao YC, Lok AS, Han KH, Goodman Z, Zhu J, Cross A, DeHertogh D, Wilber R, Colonno $R$, Apelian D (2006). A comparison of entecavir and lamivudine for HBeAg-positive chronic hepatitis B. N Engl J Med 354(10): 1001-1010.

8. Santantonio TA, Fasano M (2014). Chronic hepatitis B: Advances in treatment. World J Hepatol 6(5): 284-292.

9. Watashi K, Urban S, Li W, Wakita T (2014). NTCP and beyond: opening the door to unveil hepatitis B virus entry. Int J Mol Sci 15(2): 28922905.

10. Shepard CW, Simard EP, Finelli L, Fiore AE, Bell BP (2006). Hepatitis $B$ virus infection: epidemiology and vaccination. Epidemiol Rev 28: 112-125.

11. Liang TJ (2009). Hepatitis B: the virus and disease. Hepatology 49(5 Suppl): S13-21.

12. Coppola N, Onorato L, Minichini C, Di Caprio G, Starace M, Sagnelli $C$, Sagnelli E (2015). Clinical significance of hepatitis B surface antigen mutants. World J Hepatol 7(27): 2729-2739.

\section{CONFLICT OF INTEREST}

Potential conflicts of interest: none reported.

\section{COPYRIGHT}

(C) 2016 Inoue and Tanaka. This is an open-access article released under the terms of the Creative Commons Attribution (CC BY) license, which allows the unrestricted use, distribution, and reproduction in any medium, provided the original author and source are acknowledged.

Please cite this article as: Takako Inoue and Yasuhito Tanaka (2016). Hepatitis B virus and its sexually transmitted infection - an update. Microbial Cell 3(9): 420-437.

13. Datta S, Chatterjee S, Veer V, Chakravarty R (2012). Molecular biology of the hepatitis B virus for clinicians. J Clin Exp Hepatol 2(4): 353-365.

14. Kidd-Ljunggren K, Miyakawa Y, Kidd AH (2002). Genetic variability in hepatitis B viruses. J Gen Virol 83(Pt 6): 1267-1280.

15. Kay A, Zoulim F (2007). Hepatitis B virus genetic variability and evolution. Virus Res 127(2): 164-176.

16. Mahoney FJ (1999). Update on diagnosis, management, and prevention of hepatitis B virus infection. Clin Microbiol Rev 12(2): 351 366.

17. Bartenschlager $\mathrm{R}$, Schaller $\mathrm{H}$ (1988). The amino-terminal domain of the hepadnaviral P-gene encodes the terminal protein (genome-linked protein) believed to prime reverse transcription. Embo j 7(13): 41854192.

18. Hsu HY, Chang MH, Hsieh KH, Lee CY, Lin HH, Hwang LH, Chen PJ, Chen DS (1992). Cellular immune response to $\mathrm{HBCAg}$ in mother-toinfant transmission of hepatitis B virus. Hepatology 15(5): 770-776.

19. Chen M, Sallberg M, Hughes J, Jones J, Guidotti LG, Chisari FV, Billaud JN, Milich DR (2005). Immune tolerance split between hepatitis $B$ virus precore and core proteins. J Virol 79(5): 3016-3027.

20. Pang R, Tse E, Poon RT (2006). Molecular pathways in hepatocellular carcinoma. Cancer Lett 240(2): 157-169.

21. McMahon BJ, Alward WL, Hall DB, Heyward WL, Bender TR, Francis DP, Maynard JE (1985). Acute hepatitis B virus infection: relation of age to the clinical expression of disease and subsequent development of the carrier state. J Infect Dis 151(4): 599-603.

22. Locarnini S, Hatzakis A, Chen DS, Lok A (2015). Strategies to control hepatitis B: Public policy, epidemiology, vaccine and drugs. J Hepatol 62(1 Suppl): S76-86.

23. (2012). EASL clinical practice guidelines: Management of chronic hepatitis B virus infection. J Hepatol 57(1): 167-185.

24. Liaw YF, Chu CM (2009). Hepatitis B virus infection. Lancet 373(9663): 582-592

25. Aspinall EJ, Hawkins G, Fraser A, Hutchinson SJ, Goldberg D (2011). Hepatitis B prevention, diagnosis, treatment and care: a review. Occup Med (Lond) 61(8): 531-540. 
26. Fattovich G, Bortolotti F, Donato F (2008). Natural history of chronic hepatitis $B$ : special emphasis on disease progression and prognostic factors. J Hepatol 48(2): 335-352.

27. Hoofnagle JH, Doo E, Liang TJ, Fleischer R, Lok AS (2007). Management of hepatitis $B$ : summary of a clinical research workshop. Hepatology 45(4): 1056-1075.

28. Lok AS, McMahon BJ (2009). Chronic hepatitis B: update 2009. Hepatology 50(3): 661-662.

29. Yuen MF, Sablon E, Yuan HJ, Wong DK, Hui CK, Wong BC, Chan AO, Lai $C L$ (2003). Significance of hepatitis $B$ genotype in acute exacerbation, $\mathrm{HBeAg}$ seroconversion, cirrhosis-related complications, and hepatocellular carcinoma. Hepatology 37(3): 562-567.

30. Beasley RP, Hwang LY, Lee GC, Lan CC, Roan CH, Huang FY, Chen $C L$ (1983). Prevention of perinatally transmitted hepatitis $B$ virus infections with hepatitis $B$ immune globulin and hepatitis $B$ vaccine. Lancet 2(8359): 1099-1102.

31. Tai DI, Lin SM, Sheen IS, Chu CM, Lin DY, Liaw YF (2009). Long-term outcome of hepatitis B e antigen-negative hepatitis B surface antigen carriers in relation to changes of alanine aminotransferase levels over time. Hepatology 49(6): 1859-1867.

32. Papatheodoridis GV, Chrysanthos N, Hadziyannis E, Cholongitas E, Manesis EK (2008). Longitudinal changes in serum HBV DNA levels and predictors of progression during the natural course of HBeAg-negative chronic hepatitis B virus infection. J Viral Hepat 15(6): 434-441.

33. Martinot-Peignoux $M$, Boyer $N$, Colombat $M$, Akremi R, Pham BN Ollivier S, Castelnau C, Valla D, Degott C, Marcellin P (2002). Serum hepatitis $B$ virus DNA levels and liver histology in inactive $\mathrm{HBsAg}$ carriers. J Hepatol 36(4): 543-546.

34. Simonetti J, Bulkow L, McMahon BJ, Homan C, Snowball M, Negus S, Williams J, Livingston SE (2010). Clearance of hepatitis B surface antigen and risk of hepatocellular carcinoma in a cohort chronically infected with hepatitis B virus. Hepatology 51(5): 1531-1537.

35. Seeger C, Mason WS (2000). Hepatitis B virus biology. Microbiol Mol Biol Rev 64(1): 51-68.

36. Tuttleman JS, Pourcel C, Summers J (1986). Formation of the poo of covalently closed circular viral DNA in hepadnavirus-infected cells. Cell 47(3): 451-460

37. Yan $\mathrm{H}$, Zhong $\mathrm{G}, \mathrm{Xu} \mathrm{G}$, He $\mathrm{W}$, Jing $\mathrm{Z}$, Gao Z, Huang $\mathrm{Y}$, Qi $\mathrm{Y}$, Peng $B$, Wang $H$, Fu L, Song M, Chen P, Gao W, Ren B, Sun Y, Cai T, Feng X, Sui J, Li W (2012). Sodium taurocholate cotransporting polypeptide is a functional receptor for human hepatitis B and D virus. Elife 1(e00049).

38. Yang HC, Kao JH (2014). Persistence of hepatitis B virus covalently closed circular DNA in hepatocytes: molecular mechanisms and clinical significance. Emerg Microbes Infect 3(9): e64.

39. Gerlich WH (2013). Medical virology of hepatitis B: how it began and where we are now. Virol J 10: 239.

40. WHO (2016). Hepatitis B: Surveillance and control, Available: http://www.who.int/csr/disease/hepatitis/whocdscsrlyo20022/en/ind ex4.html . Accessed: 04.12.2015.

41. Hawkins C, Christian B, Ye J, Nagu T, Aris E, Chalamilla G, Spiegelman D, Mugusi F, Mehta S, Fawzi W (2013). Prevalence of hepatitis B co-infection and response to antiretroviral therapy among HIVinfected patients in Tanzania. Aids 27(6): 919-927.

42. Wandeler G, Gsponer T, Bihl F, Bernasconi E, Cavassini M, Kovar H, Schmid P, Battegay M, Calmy A, Egger M, Furrer H, Rauch A (2013). Hepatitis $B$ virus infection is associated with impaired immunological recovery during antiretroviral therapy in the Swiss HIV cohort study. J Infect Dis 208(9): 1454-1458.
43. Nikolopoulos GK, Paraskevis D, Hatzitheodorou E, Moschidis Z, Sypsa V, Zavitsanos X, Kalapothaki V, Hatzakis A (2009). Impact of hepatitis $B$ virus infection on the progression of AIDS and mortality in HIV-infected individuals: a cohort study and meta-analysis. Clin Infect Dis 48(12): 1763-1771.

44. Chun HM, Roediger MP, Hullsiek KH, Thio CL, Agan BK, Bradley WP, Peel SA, Jagodzinski LL, Weintrob AC, Ganesan A, Wortmann G, Crum-Cianflone NF, Maguire JD, Landrum ML (2012). Hepatitis B virus coinfection negatively impacts HIV outcomes in HIV seroconverters. J Infect Dis 205(2): 185-193.

45. Modi AA, Feld JJ (2007). Viral hepatitis and HIV in Africa. AIDS Rev 9(1): 25-39.

46. Easterbrook P, Sands A, Harmanci H (2012). Challenges and priorities in the management of HIV/HBV and HIV/HCV coinfection in resource-limited settings. Semin Liver Dis 32(2): 147-157.

47. WHO (2016) "Hepatitis B: Fact sheet", Available: http://www.who.int/mediacentre/factsheets/fs204/en/ . Accessed: 29.04.2016.

48. Te HS, Jensen DM (2010). Epidemiology of hepatitis B and C viruses: a global overview. Clin Liver Dis 14(1): 1-21, vii.

49. Kwak MS, Kim YJ (2014). Occult hepatitis B virus infection. World J Hepatol 6(12): 860-869.

50. Thedja MD, Muljono DH, le SI, Sidarta E, Turyadi, Verhoef J, Marzuki S (2015). Genogeography and Immune Epitope Characteristics of Hepatitis B Virus Genotype C Reveals Two Distinct Types: Asian and Papua-Pacific. PLoS One 10(7): e0132533

51. Kuo A, Gish R (2012). Chronic hepatitis B infection. Clin Liver Dis 16(2): 347-369.

52. Kurbanov F, Tanaka Y, Mizokami M (2010). Geographical and genetic diversity of the human hepatitis B virus. Hepatol Res 40(1): 1430

53. Tatematsu K, Tanaka Y, Kurbanov F, Sugauchi F, Mano S, Maeshiro T, Nakayoshi T, Wakuta M, Miyakawa Y, Mizokami M (2009). A genetic variant of hepatitis $B$ virus divergent from known human and ape genotypes isolated from a Japanese patient and provisionally assigned to new genotype J. J Virol 83(20): 10538-10547.

54. Soriano V, Mocroft A, Peters L, Rockstroh J, Antunes F, Kirkby N de Wit S, Monforte A, Flisiak R, Lundgren J (2010). Predictors of hepatitis B virus genotype and viraemia in HIV-infected patients with chronic hepatitis B in Europe. J Antimicrob Chemother 65(3): 548-555.

55. Trimoulet $P$, Boutonnet $M$, Winnock $M$, Faure $M$, Loko MA, De Ledinghen V, Bernard PH, Castera L, Foucher J, Dupon M, Ragnaud JM, Lafon ME, Couzigou P, Dabis F, Fleury H, Neau D (2007). Hepatitis B virus genotypes: a retrospective survey in Southwestern France, 19992004. Gastroenterol Clin Biol 31(12): 1088-1094.

56. Fujisaki S, Yokomaku Y, Shiino T, Koibuchi T, Hattori J, Ibe S, Iwatani $Y$, Iwamoto A, Shirasaka T, Hamaguchi M, Sugiura W (2011). Outbreak of infections by hepatitis $B$ virus genotype $A$ and transmission of genetic drug resistance in patients coinfected with HIV-1 in Japan. J Clin Microbiol 49(3): 1017-1024.

57. Araujo NM, Waizbort R, Kay A (2011). Hepatitis B virus infection from an evolutionary point of view: how viral, host, and environmental factors shape genotypes and subgenotypes. Infect Genet Evol 11(6): 1199-1207.

58. Ito K, Yotsuyanagi $\mathrm{H}$, Yatsuhashi $\mathrm{H}$, Karino $\mathrm{Y}$, Takikawa $\mathrm{Y}$, Saito $\mathrm{T}$, Arase $Y$, Imazeki $F$, Kurosaki $M$, Umemura $T$, Ichida $T$, Toyoda $H$, Yoneda M, Mita E, Yamamoto K, Michitaka K, Maeshiro T, Tanuma J, Tanaka Y, Sugiyama M, Murata K, Masaki N, Mizokami M (2014). Risk factors for long-term persistence of serum hepatitis $B$ surface antigen 
following acute hepatitis B virus infection in Japanese adults. Hepatology 59(1): 89-97.

59. Ito K, Yotsuyanagi $H$, Sugiyama $M$, Yatsuhashi $H$, Karino $Y$, Takikawa $Y$, Saito $T$, Arase $Y$, Imazeki $F$, Kurosaki M, Umemura T, Ichida $T$, Toyoda H, Yoneda M, Tanaka Y, Mita E, Yamamoto K, Michitaka K, Maeshiro T, Tanuma J, Korenaga M, Murata K, Masaki N, Koike K, Mizokami M (2016). Geographic distribution and characteristics of genotype $A$ hepatitis $B$ virus infection in acute and chronic hepatitis $B$ patients in Japan. J Gastroenterol Hepatol 31(1): 180-189.

60. Fung SK, Lok AS (2004). Hepatitis B virus genotypes: do they play a role in the outcome of HBV infection? Hepatology 40(4): 790-792.

61. Croagh CM, Desmond PV, Bell SJ (2015). Genotypes and viral variants in chronic hepatitis B: A review of epidemiology and clinical relevance. World J Hepatol 7(3): 289-303.

62. Marciano S, Galdame OA, Gadano AC (2013). HBV genotype F: natural history and treatment. Antivir Ther 18(3 Pt B): 485-488.

63. Chu CM, Liaw YF (2005). Genotype C hepatitis B virus infection is associated with a higher risk of reactivation of hepatitis $B$ and progression to cirrhosis than genotype $\mathrm{B}$ : a longitudinal study of hepatitis $B$ e antigen-positive patients with normal aminotransferase levels at baseline. J Hepatol 43(3): 411-417.

64. Chan HL, Wong GL, Tse $\mathrm{CH}$, Chim AM, Yiu KK, Chan HY, Sung JJ, Wong VW (2009). Hepatitis $B$ virus genotype $C$ is associated with more severe liver fibrosis than genotype B. Clin Gastroenterol Hepatol 7(12): 1361-1366.

65. Lee MH, Yang HI, Liu J, Batrla-Utermann R, Jen CL, lloeje UH, Lu SN, You SL, Wang LY, Chen CJ (2013). Prediction models of long-term cirrhosis and hepatocellular carcinoma risk in chronic hepatitis B patients: risk scores integrating host and virus profiles. Hepatology 58(2): 546-554.

66. Tanaka $Y$, Mukaide $M$, Orito $E$, Yuen MF, Ito K, Kurbanov F, Sugauchi F, Asahina Y, Izumi N, Kato M, Lai CL, Ueda R, Mizokami M (2006). Specific mutations in enhancer II/core promoter of hepatitis $B$ virus subgenotypes $\mathrm{C} 1 / \mathrm{C} 2$ increase the risk of hepatocellular carcinoma. J Hepatol 45(5): 646-653.

67. McMahon BJ (2010). Natural history of chronic hepatitis B. Clin Liver Dis 14(3): 381-396.

68. Kramvis A, Kew M, Francois G (2005). Hepatitis B virus genotypes. Vaccine 23(19): 2409-2423.

69. Tanaka Y, Hasegawa I, Kato T, Orito E, Hirashima N, Acharya SK, Gish RG, Kramvis A, Kew MC, Yoshihara N, Shrestha SM, Khan M, Miyakawa Y, Mizokami M (2004). A case-control study for differences among hepatitis $B$ virus infections of genotypes $A$ (subtypes $A a$ and Ae) and D. Hepatology 40(3): 747-755.

70. Ferrell L (2000). Liver pathology: cirrhosis, hepatitis, and primary liver tumors. Update and diagnostic problems. Mod Pathol 13(6): 679704.

71. Mani H, Kleiner DE (2009). Liver biopsy findings in chronic hepatitis B. Hepatology 49(5 Suppl): S61-71.

72. Theise ND (2007). Liver biopsy assessment in chronic viral hepatitis: a personal, practical approach. Mod Pathol 20 Suppl 1(S3-14).

73. Su IJ, Wang HC, Wu HC, Huang WY (2008). Ground glass hepatocytes contain pre-S mutants and represent preneoplastic lesions in chronic hepatitis B virus infection. J Gastroenterol Hepatol 23(8 Pt 1): 1169-1174.

74. Sagnelli C, Ciccozzi M, Pisaturo M, Lo Presti A, Cella E, Coppola N, Sagnelli E (2015). The impact of viral molecular diversity on the clinical presentation and outcome of acute hepatitis B in Italy. New Microbiol 38(2): 137-147.
75. Krugman S, Overby LR, Mushahwar IK, Ling CM, Frosner GG, Deinhardt $F$ (1979). Viral hepatitis, type B. Studies on natural history and prevention re-examined. N Engl J Med 300(3): 101-106.

76. Hoofnagle JH, Di Bisceglie AM (1991). Serologic diagnosis of acute and chronic viral hepatitis. Semin Liver Dis 11(2): 73-83.

77. McMahon BJ, Holck P, Bulkow L, Snowball M (2001). Serologic and clinical outcomes of 1536 Alaska Natives chronically infected with hepatitis B virus. Ann Intern Med 135(9): 759-768.

78. Alward WL, McMahon BJ, Hall DB, Heyward WL, Francis DP, Bender TR (1985). The long-term serological course of asymptomatic hepatitis $B$ virus carriers and the development of primary hepatocellular carcinoma. J Infect Dis 151(4): 604-609.

79. Liaw YF, Sheen IS, Chen TJ, Chu CM, Pao CC (1991). Incidence, determinants and significance of delayed clearance of serum HBsAg in chronic hepatitis $B$ virus infection: a prospective study. Hepatology 13(4): 627-631.

80. Adachi $H$, Kaneko S, Matsushita $E$, Inagaki $Y$, Unoura $M$, Kobayashi $\mathrm{K}$ (1992). Clearance of HBsAg in seven patients with chronic hepatitis B. Hepatology 16(6): 1334-1337.

81. Beasley RP, Hwang LY, Lin CC, Chien CS (1981). Hepatocellular carcinoma and hepatitis B virus. A prospective study of 22707 men in Taiwan. Lancet 2(8256): 1129-1133.

82. McMahon BJ, Alberts SR, Wainwright RB, Bulkow L, Lanier AP (1990). Hepatitis B-related sequelae. Prospective study in 1400 hepatitis B surface antigen-positive Alaska native carriers. Arch Intern Med 150(5): 1051-1054.

83. Brook MG (2002). Sexually acquired hepatitis. Sex Transm Infect 78(4): 235-240.

84. Terrault N, Roche B, Samuel D (2005). Management of the hepatitis $B$ virus in the liver transplantation setting: a European and an American perspective. Liver Transpl 11(7): 716-732.

85. Gan SI, Devlin SM, Scott-Douglas NW, Burak KW (2005). Lamivudine for the treatment of membranous glomerulopathy secondary to chronic Hepatitis B infection. Can J Gastroenterol 19(10): 625-629.

86. Dienstag JL (1981). Hepatitis B as an immune complex disease. Semin Liver Dis 1(1): 45-57.

87. Trepo C, Guillevin L (2001). Polyarteritis nodosa and extrahepatic manifestations of HBV infection: the case against autoimmune intervention in pathogenesis. J Autoimmun 16(3): 269-274.

88. Alpert E, Isselbacher KJ, Schur PH (1971). The pathogenesis of arthritis associated with viral hepatitis. Complement-component studies. N Engl J Med 285(4): 185-189.

89. Gocke DJ, Hsu K, Morgan C, Bombardieri S, Lockshin M, Christian $\mathrm{CL}$ (1970). Association between polyarteritis and Australia antigen. Lancet 2(7684): 1149-1153.

90. Lai KN, Li PK, Lui SF, Au TC, Tam JS, Tong KL, Lai FM (1991). Membranous nephropathy related to hepatitis B virus in adults. $\mathbf{N}$ Engl J Med 324(21): 1457-1463.

91. Takekoshi Y, Tanaka M, Shida N, Satake Y, Saheki Y, Matsumoto S (1978). Strong association between membranous nephropathy and hepatitis-B surface antigenaemia in Japanese children. Lancet 2(8099): 1065-1068.

92. Lin CL, Liao LY, Liu CJ, Yu MW, Chen PJ, Lai MY, Chen DS, Kao JH (2007). Hepatitis B viral factors in HBeAg-negative carriers with persistently normal serum alanine aminotransferase levels. Hepatology 45(5): 1193-1198

93. Dietzman DE, Harnisch JP, Ray CG, Alexander ER, Holmes KK (1977). Hepatitis B surface antigen ( $\mathrm{HBsAg}$ ) and antibody to $\mathrm{HBsAg}$. 
Prevalence in homosexual and heterosexual men. Jama 238(24): 2625-2626.

94. MacKellar DA, Valleroy LA, Secura GM, McFarland W, Shehan D, Ford W, LaLota M, Celentano DD, Koblin BA, Torian LV, Thiede H, Janssen RS (2001). Two decades after vaccine license: hepatitis $B$ immunization and infection among young men who have sex with men. Am J Public Health 91(6): 965-971.

95. Kao JH (2008). Diagnosis of hepatitis B virus infection through serological and virological markers. Expert Rev Gastroenterol Hepatol 2(4): 553-562

96. Yao GB (1996). Importance of perinatal versus horizontal transmission of hepatitis B virus infection in China. Gut 38 Suppl 2(S39-42).

97. Van Damme P, Cramm M, Van der Auwera JC, Vranckx R, Meheus A (1995). Horizontal transmission of hepatitis B virus. Lancet 345(8941): 27-29.

98. Alter MJ, Ahtone J, Weisfuse I, Starko K, Vacalis TD, Maynard JE (1986). Hepatitis $B$ virus transmission between heterosexuals. Jama 256(10): 1307-1310.

99. Alter MJ, Coleman PJ, Alexander WJ, Kramer E, Miller JK, Mandel E, Hadler SC, Margolis HS (1989). Importance of heterosexual activity in the transmission of hepatitis $B$ and non- $A$, non- $B$ hepatitis. Jama 262(9): 1201-1205.

100. Miller KE, Ruiz DE, Graves JC (2003). Update on the prevention and treatment of sexually transmitted diseases. Am Fam Physician 67(9): 1915-1922.

101. Crosby RA, Newman D, Kamb ML, Zenilman J, Douglas J, latesta $M$ (2000). Misconceptions about STD-protective behavior. Project RESPECT Study Group. Am J Prev Med 19(3): 167-173.

102. Catania JA, Canchola J, Binson D, Dolcini MM, Paul JP, Fisher L, Choi KH, Pollack L, Chang J, Yarber WL, Heiman JR, Coates T (2001). National trends in condom use among at-risk heterosexuals in the united states. J Acquir Immune Defic Syndr 27(2): 176-182.

103. Mast EE, Margolis HS, Fiore AE, Brink EW, Goldstein ST, Wang SA, Moyer LA, Bell BP, Alter MJ (2005). A comprehensive immunization strategy to eliminate transmission of hepatitis $B$ virus infection in the United States: recommendations of the Advisory Committee on Immunization Practices (ACIP) part 1: immunization of infants, children, and adolescents. MMWR Recomm Rep 54(Rr-16): 1-31.

104. Mast EE, Weinbaum CM, Fiore AE, Alter MJ, Bell BP, Finelli L, Rodewald LE, Douglas JM, Jr., Janssen RS, Ward JW (2006). A comprehensive immunization strategy to eliminate transmission of hepatitis $B$ virus infection in the United States: recommendations of the Advisory Committee on Immunization Practices (ACIP) Part II: immunization of adults. MMWR Recomm Rep 55(Rr-16): 1-33; quiz CE31-34.

105. Valenzuela P, Medina A, Rutter WJ, Ammerer G, Hall BD (1982). Synthesis and assembly of hepatitis $B$ virus surface antigen particles in yeast. Nature 298(5872): 347-350.

106. Niu MT, Salive ME, Ellenberg SS (1999). Neonatal deaths after hepatitis B vaccine: the vaccine adverse event reporting system, 19911998. Arch Pediatr Adolesc Med 153(12): 1279-1282.

107. Eriksen EM, Perlman JA, Miller A, Marcy SM, Lee H, Vadheim C, Zangwill KM, Chen RT, DeStefano F, Lewis E, Black S, Shinefield $H$, Ward JI (2004). Lack of association between hepatitis B birth immunization and neonatal death: a population-based study from the vaccine safety datalink project. Pediatr Infect Dis J 23(7): 656-662.

108. Chen DS (2009). Hepatitis B vaccination: The key towards elimination and eradication of hepatitis B. J Hepatol 50(4): 805-816.

109. Arevalo JA, Washington AE (1988). Cost-effectiveness of prenatal screening and immunization for hepatitis B virus. Jama 259(3): 365369.
110. Chen DS, Hsu NH, Sung JL, Hsu TC, Hsu ST, Kuo YT, Lo KJ, Shih YT (1987). A mass vaccination program in Taiwan against hepatitis $B$ virus infection in infants of hepatitis B surface antigen-carrier mothers. Jama 257(19): 2597-2603.

111. Spradling PR, Xing J, Williams R, Masunu-Faleafaga $Y$, Dulski T, Mahamud A, Drobeniuc J, Teshale EH (2013). Immunity to hepatitis B virus (HBV) infection two decades after implementation of universal infant HBV vaccination: association of detectable residual antibodies and response to a single HBV challenge dose. Clin Vaccine Immunol 20(4): 559-561.

112. Mendy $M$, Peterson $I$, Hossin $S$, Peto $T$, Jobarteh $M L$, Jeng-Barry A, Sidibeh M, Jatta A, Moore SE, Hall AJ, Whittle H (2013). Observational study of vaccine efficacy 24 years after the start of hepatitis $B$ vaccination in two Gambian villages: no need for a booster dose. PLoS One 8(3): e58029.

113. Poovorawan $\mathrm{Y}$, Chongsrisawat $\mathrm{V}$, Theamboonlers $\mathrm{A}$, Leroux-Roels G, Crasta PD, Hardt K (2012). Persistence and immune memory to hepatitis $B$ vaccine 20 years after primary vaccination of Thai infants, born to HBsAg and HBeAg positive mothers. Hum Vaccin Immunother 8(7): 896-904

114. Stramer SL, Wend U, Candotti D, Foster GA, Hollinger FB, Dodd RY, Allain JP, Gerlich W (2011). Nucleic acid testing to detect HBV infection in blood donors. N Engl J Med 364(3): 236-247.

115. Boot HJ, van der Waaij LA, Schirm J, Kallenberg CG, van Steenbergen J, Wolters B (2009). Acute hepatitis B in a healthcare worker: a case report of genuine vaccination failure. J Hepatol 50(2): 426-431.

116. O'Halloran JA, De Gascun CF, Dunford L, Carr MJ, Connell J, Howard R, Hall WW, Lambert JS (2011). Hepatitis B virus vaccine failure resulting in chronic hepatitis B infection. J Clin Virol 52(2): 151-154.

117. Kane M (1995). Global programme for control of hepatitis $B$ infection. Vaccine 13 Suppl 1(S47-49).

118. Schillie S, Murphy TV, Sawyer M, Ly K, Hughes E, Jiles R, de Perio MA, Reilly M, Byrd K, Ward JW (2013). CDC guidance for evaluating health-care personnel for hepatitis $B$ virus protection and for administering postexposure management. MMWR Recomm Rep 62(Rr-10): 119.

119. Sorrell MF, Belongia EA, Costa J, Gareen IF, Grem JL, Inadomi JM, Kern ER, McHugh JA, Petersen GM, Rein MF, Strader DB, Trotter HT (2009). National Institutes of Health consensus development conference statement: management of hepatitis B. Hepatology 49(5 Suppl): S4-S12.

120. Nebbia G, Peppa D, Maini MK (2012). Hepatitis B infection: current concepts and future challenges. Qjm 105(2): 109-113.

121. Kim BK, Han KH, Ahn SH (2011). Prevention of hepatocellular carcinoma in patients with chronic hepatitis B virus infection. Oncology 81 Suppl 1(41-49).

122. Scott KC, Taylor EM, Mamo B, Herr ND, Cronkright PJ, Yun K, Altshuler M, Shetty S (2015). Hepatitis B screening and prevalence among resettled refugees - United States, 2006-2011. MMWR Morb Mortal Wkly Rep 64(21): 570-573.

123. Liaw YF, Leung N, Kao JH, Piratvisuth T, Gane E, Han KH, Guan R, Lau GK, Locarnini S (2008). Asian-Pacific consensus statement on the management of chronic hepatitis B: a 2008 update. Hepatol Int 2(3): 263-283.

124. Sherman M, Shafran S, Burak K, Doucette K, Wong W, Girgrah N, Yoshida E, Renner E, Wong P, Deschenes M (2007). Management of chronic hepatitis B: consensus guidelines. Can J Gastroenterol 21 Suppl $C(5 c-24 c)$

125. Kennedy PT, Lee $H C$, Jeyalingam L, Malik R, Karayiannis $P$, Muir D, Main J, Thursz M, Goldin R, Smith B, Brown A, Thomas HC (2008). NICE 
guidelines and a treatment algorithm for the management of chronic hepatitis B: a review of 12 years experience in west London. Antivir Ther 13(8): 1067-1076.

126. Sorrell MF, Belongia EA, Costa J, Gareen IF, Grem JL, Inadomi JM, Kern ER, McHugh JA, Petersen GM, Rein MF, Strader DB, Trotter HT (2009). National Institutes of Health Consensus Development Conference Statement: management of hepatitis B. Ann Intern Med 150(2): 104-110.

127. Soriano V, de Mendoza C, Pena JM, Barreiro P (2015). Advances in treating drug-resistant hepatitis B virus in HIV-infected patients. Expert Opin Pharmacother 16(2): 179-186.

128. Deny P, Zoulim F (2010). Hepatitis B virus: from diagnosis to treatment. Pathol Biol (Paris) 58(4): 245-253.

129. Mutimer D, Naoumov N, Honkoop P, Marinos G, Ahmed M, de Man R, McPhillips P, Johnson M, Williams R, Elias E, Schalm S (1998). Combination alpha-interferon and lamivudine therapy for alphainterferon-resistant chronic hepatitis B infection: results of a pilot study. J Hepatol 28(6): 923-929.

130. Lau GK, Piratvisuth T, Luo KX, Marcellin P, Thongsawat S, Cooksley G, Gane E, Fried MW, Chow WC, Paik SW, Chang WY, Berg T, Flisiak $\mathrm{R}$, McCloud P, Pluck N (2005). Peginterferon Alfa-2a, lamivudine, and the combination for HBeAg-positive chronic hepatitis B. N Engl J Med 352(26): 2682-2695.

131. Carey I, Harrison PM (2009). Monotherapy versus combination therapy for the treatment of chronic hepatitis B. Expert Opin Investig Drugs 18(11): 1655-1666.

132. Erhardt A, Blondin D, Hauck K, Sagir A, Kohnle T, Heintges $T$, Haussinger D (2005). Response to interferon alfa is hepatitis $B$ virus genotype dependent: genotype $A$ is more sensitive to interferon than genotype D. Gut 54(7): 1009-1013.

133. Wong GL, Wong VW, Chan HY, Tse PC, Wong J, Chim AM, Yiu KK Chu SH, Chan HL (2012). Undetectable HBV DNA at month 12 of entecavir treatment predicts maintained viral suppression and $\mathrm{HBeAg}$ seroconversion in chronic hepatitis B patients at 3 years. Aliment Pharmacol Ther 35(11): 1326-1335.

134. Chang TT, Lai CL, Kew Yoon S, Lee SS, Coelho HS, Carrilho FJ, Poordad F, Halota W, Horsmans Y, Tsai N, Zhang H, Tenney DJ, Tamez $R$, lloeje $U$ (2010). Entecavir treatment for up to 5 years in patients with hepatitis B e antigen-positive chronic hepatitis B. Hepatology 51(2): 422-430.

135. Schiff ER, Lee SS, Chao YC, Kew Yoon S, Bessone F, Wu SS, Kryczka W, Lurie Y, Gadano A, Kitis G, Beebe S, Xu D, Tang H, lloeje U (2011). Long-term treatment with entecavir induces reversal of advanced fibrosis or cirrhosis in patients with chronic hepatitis B. Clin Gastroenterol Hepatol 9(3): 274-276
136. Marcellin P, Gane E, Buti M, Afdhal N, Sievert W, Jacobson IM, Washington MK, Germanidis G, Flaherty JF, Schall RA, Bornstein JD Kitrinos KM, Subramanian GM, McHutchison JG, Heathcote EJ (2013). Regression of cirrhosis during treatment with tenofovir disoproxi fumarate for chronic hepatitis B: a 5-year open-label follow-up study. Lancet 381(9865): 468-475.

137. El-Serag HB, Davila JA (2011). Surveillance for hepatocellular carcinoma: in whom and how? Therap Adv Gastroenterol 4(1): 5-10.

138. Rehermann B, Bertoletti A (2015). Immunological aspects of antiviral therapy of chronic hepatitis $B$ virus and hepatitis $C$ virus infections. Hepatology 61(2): 712-721.

139. Shafritz DA, Shouval D, Sherman HI, Hadziyannis SJ, Kew MC (1981). Integration of hepatitis B virus DNA into the genome of liver cells in chronic liver disease and hepatocellular carcinoma. Studies in percutaneous liver biopsies and post-mortem tissue specimens. $\mathbf{N}$ Engl J Med 305(18): 1067-1073.

140. Block TM, Gish R, Guo H, Mehta A, Cuconati A, Thomas London W, Guo JT (2013). Chronic hepatitis B: what should be the goal for new therapies? Antiviral Res 98(1): 27-34.

141. Fattovich G, Stroffolini T, Zagni I, Donato F (2004). Hepatocellular carcinoma in cirrhosis: incidence and risk factors. Gastroenterology 127(5 Suppl 1): S35-50.

142. Reddy KR, Beavers KL, Hammond SP, Lim JK, Falck-Ytter YT (2015). American Gastroenterological Association Institute guideline on the prevention and treatment of hepatitis B virus reactivation during immunosuppressive drug therapy. Gastroenterology 148(1) 215-219; quiz e216-217.

143. Perrillo RP, Gish R, Falck-Ytter YT (2015). American Gastroenterological Association Institute technical review on prevention and treatment of hepatitis $B$ virus reactivation during immunosuppressive drug therapy. Gastroenterology 148(1): 221-244.e223.

144. Pollicino T, Raimondo G (2014). Occult hepatitis B infection. J Hepatol 61(3): 688-689.

145. Liu J, Yang HI, Lee MH, Lu SN, Jen CL, Batrla-Utermann R, Wang LY, You SL, Hsiao CK, Chen PJ, Chen CJ (2014). Spontaneous seroclearance of hepatitis B seromarkers and subsequent risk of hepatocellular carcinoma. Gut 63(10): 1648-1657.

146. Hadziyannis SJ, Sevastianos V, Rapti I, Vassilopoulos D, Hadziyannis E (2012). Sustained responses and loss of HBsAg in $\mathrm{HBeAg}$ negative patients with chronic hepatitis $B$ who stop long-term treatment with adefovir. Gastroenterology 143(3): 629-636.e621.

147. Hadziyannis E, Hadziyannis SJ (2014). Hepatitis B surface antigen quantification in chronic hepatitis B and its clinical utility. Expert Rev Gastroenterol Hepatol 8(2): 185-195. 